\title{
Molecular anatomy of the gut-brain axis revealed with transgenic technologies: implications in metabolic research
}

\author{
Swalpa Udit and Laurent Gautron* \\ Division of Hypothalamic Research, Department of Internal Medicine, University of Texas Southwestern Medical Center at Dallas, Dallas, TX, USA
}

\author{
Edited by: \\ Kevin W. Williams, The University of \\ Texas Southwestern Medical \\ Center, USA \\ Reviewed by: \\ Amanda J. Page, Hanson Institute, \\ Australia \\ Julie A. Chowen, Hospital Infantil \\ Universitario Niño Jesús, Spain \\ Gary Schwartz, Albert Einstein \\ College of Medicine of Yeshiva \\ University, USA \\ *Correspondence: \\ Laurent Gautron, Division of \\ Hypothalamic Research, \\ Department of Internal Medicine, \\ University of Texas Southwestern \\ Medical Center at Dallas, 5323 \\ Harry Hines BIvd, Y6.220C - Dallas, \\ TX 75390-9077, USA \\ e-mail: laurent.gautron@ \\ utsouthwestern.edu
}

Neurons residing in the gut-brain axis remain understudied despite their important role in coordinating metabolic functions. This lack of knowledge is observed, in part, because labeling gut-brain axis neurons and their connections using conventional neuroanatomical methods is inherently challenging. This article summarizes genetic approaches that enable the labeling of distinct populations of gut-brain axis neurons in living laboratory rodents. In particular, we review the respective strengths and limitations of currently available genetic and viral approaches that permit the marking of gut-brain axis neurons without the need for antibodies or conventional neurotropic tracers. Finally, we discuss how these methodological advances are progressively transforming the study of the healthy and diseased gut-brain axis in the context of its role in chronic metabolic diseases, including diabetes and obesity.

Keywords: vagus nerve, mouse models, autonomic nervous system, morphology, obesity
"These nerves [to the bowels] are but small, because the parts serving for nutrition, needed none but little nerves, for the performance of the third duty of the nerves, which is in the discerning and knowing of what is troublesome to them [...]. We have this benefit by this sense, that as soon as anything troubles and vellicates the bowels, we being admonished thereof may look for help in time"

-Ambroise Paré, circa 1579.

\section{OVERVIEW OF THE ANATOMICAL STUDY OF THE GUT-BRAIN AXIS}

The gut-brain axis comprises a network of autonomic neurons that connect the central nervous system (CNS)—specifically, the caudal brainstem and spinal cord-to the esophagus, gastrointestinal tract, liver, and pancreas (Loewy and Spyer, 1990; Janig, 1996; Powley, 2000; Gibbins et al., 2003; Furness, 2006). The axons of these neurons travel through the vagus, splanchnic, mesenteric and pelvic spinal nerves to innervate the abdominal

\footnotetext{
Abbreviations: $\mathrm{AP}$, area postrema; $\mathrm{BAC}$, bacterial artificial chromosome; $\beta$-gal, $\beta$-galactosidase; CNS, central nervous system; CGRP, calcitonin gene-related peptide; ChAT, choline acetyltransferase; CMV, cytomegalovirus; Cre, Crerecombinase; $\mathrm{DBH}$, dopamine $\beta$-hydroxylase; DMV, dorsal motor nucleus of the vagus; DRG, dorsal root ganglion; eGFP, enhanced GFP; eGFPf, enhanced GFP farnesylated; GAD, glutamic acid decarboxylase; GHSR, ghrelin receptor; GFP, green fluorescent protein; IML, intermediolateral cell column; IRES, internal ribosome entry site; MC4R, melanocortin-4 receptor; mp, myenteric plexus; NTS, nucleus of solitary tract; NG, nodose ganglion; PNS, peripheral nervous system; Phox2b, paired-like homeobox 2b; POMC, proopiomelanocortin; PRS, noradrenergicspecific Cis element; preSVG, prevertebral sympathetic ganglion; rAAV, recombinant adeno-associated viruses; RSV, rous sarcoma virus; smp, submucosal plexus; $\mathrm{TB}$, transcription blocker; TH, tyrosine hydroxylase; UTR, untranslated region; X, vagus nerve.
}

viscera. Figure 1 provides a simplified overview of the anatomy of the mammalian gut-brain axis and its major components. While the general organization of the gut-brain axis appears relatively simple compared to that of the CNS, the neurochemical, anatomical and functional relationships between different populations of gut-brain axis neurons can be highly complex (Anlauf et al., 2003; Travagli et al., 2003; Powley et al., 2005; Lomax et al., 2006; Bertrand, 2009; Brierley, 2010; Fox, 2013). Notably, the anatomical study of gut-brain axis has a remarkably long history. For instance, the vagus nerve was already known to Galen (circa A.D. 130-200) (Ackerknecht, 1974). Furthermore, Renaissance physicians were aware of the importance of the nerve supply to the gut in discerning, as put by Ambroise Paré (Paré, 1968), what is troublesome to the bowels. However, the detailed anatomy of the gut-brain axis remained inaccessible to biologists for a long time because the nerves immediately cease to be distinguishable as they penetrate into peripheral organs. Thus, it was not until the late nineteenth century that postganglionic neurons located in the gastrointestinal wall (also known as enteric neurons) were discovered by Auerbach and Meissner (Meissner, 1857; Auerbach, 1863). Enteric neurons, along with postganglionic neurons in the gallbladder and pancreas, are part of the gut-brain axis, as they receive direct input from, and transmit information to, the rest of the autonomic nervous system; however, enteric neurons are also capable of operating independently of the gut-brain axis (Gershon, 1981; Morris et al., 1985; Mawe et al., 1997; Powley, 2000).

Using Golgi staining (DeFelipe, 2010), histologists in the beginning of the twentieth century continuously refined our 


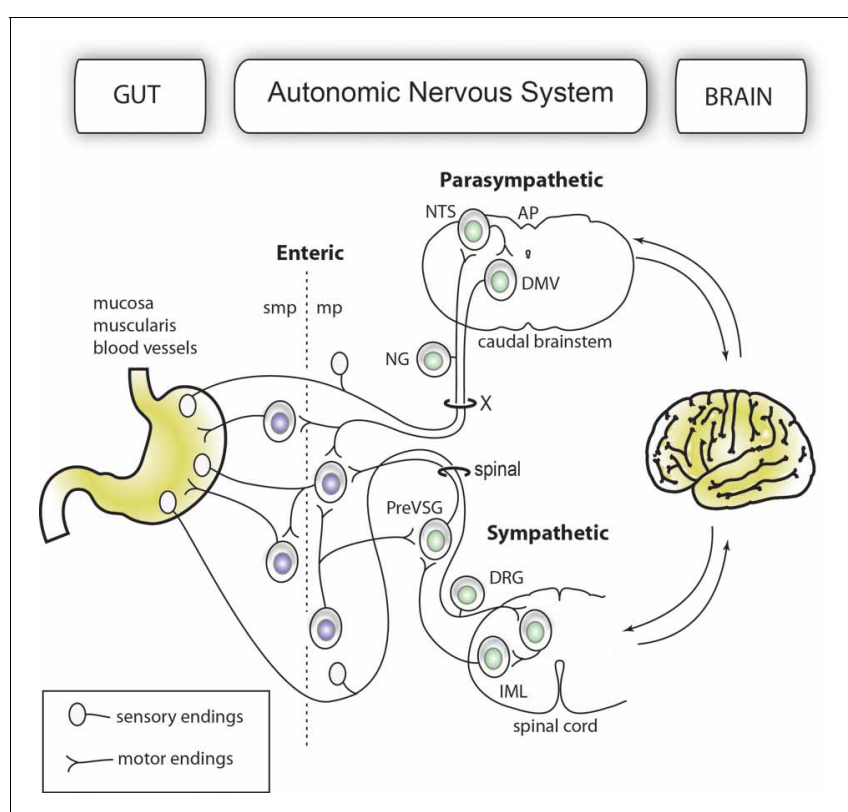

FIGURE 1 | Simplified organization of the gut-brain axis. The main anatomical and functional subdivisions of a mammalian gut-brain axis are represented with neurons belonging to the enteric and extrinsic autonomic systems in different colors. Importantly, the enteric nervous system is entirely contained within the gastrointestinal wall. For purposes of simplification, all the nerve branches supplying the gut, pancreatic post-ganglionic neurons and the sacral parasympathetic system are not depicted in this figure.

understanding of the intricate networks of neurons of the gut-brain axis. Despite its indubitable value, Golgi staining remained capricious. As a result, neuroanatomists have developed more reliable ways of interrogating the organization of the gutbrain axis in recent decades. First, a large number of anatomical studies using the injection of retrograde tracers or neurotropic viruses into visceral tissues have revealed the connections between autonomic nerves and their gastrointestinal targets (Sharkey et al., 1984; Sterner et al., 1985; Altschuler et al., 1989; Rinaman et al., 1999; Rinaman and Schwartz, 2004). Although useful, these newer approaches did not provide a means of labeling autonomic peripheral endings. In addition, retrograde tracing techniques (gut-to-brain) using neurotropic viruses or tracers to verify connections between autonomic neurons and peripheral tissues can potentially produce false-positive results (Fox and Powley, 1986; Berthoud et al., 2006). Moreover, the interpretation of data obtained with neurotropic rabies virus (which travels in a multisynaptic manner) is complicated by the fact that the vagus nerve innervates sympathetic and pelvic ganglia (Berthoud and Powley, 1993), which makes it difficult to ascertain the neural routes taken by these viruses. Alternatively, immunolabeling can be useful in identifying select neuropeptides, neurotransmitters, enzymes and receptors found in vagal and/or spinal visceral endings (Furness and Costa, 1980; Green and Dockray, 1987; Patterson et al., 2002; Chiocchetti et al., 2003; Wang and Neuhuber, 2003; Lindsay et al., 2006; Phillips and Powley, 2007; Mitsui, 2009; Bellier and Kimura, 2011). Unfortunately, specific molecular markers that could be used to selectively label different types of autonomic nerve endings in a systematic manner are still lacking. In addition, the staining obtained with antibodies might not always be distributed evenly in a neuron, and the expression levels of many molecular markers can fluctuate due to experimental conditions. Second, studies employing anterograde tracer (brain-to-gut) injections have been essential to our current understanding of the basic morphology and anatomical distribution of gut-brain axis neurons (Berthoud et al., 1991; Fox et al., 2000; Wang and Powley, 2000; Walter et al., 2009; Zagorodnyuk et al., 2010). Needless to say, those previous studies have served as invaluable references for scientists interested in the gut-brain axis and have revealed many different types of specialized neuronal endings with distinct shapes, functions and tissue distributions in the gut. Details of the variety of receptors found in the gut are available in several publications (Fox et al., 2000; Berthoud et al., 2004; Powley et al., 2011). On a more practical level, however, tracer experiments inherently produce variable results and some degree of tissue damage at the site of injection. Furthermore, tracer injections are laborious and are not always compatible with long-term physiological experiments given the relatively short life of conventional neural tracers, and, in the case of peripheral ganglia, tracer injections remain technically challenging.

Due to the aforementioned limitations, there are still gaps in our knowledge of the impact of various physiological and pathophysiological conditions on gut innervation. A better understanding of the anatomy and plasticity of the gut-brain axis will help to advance our understanding of autonomic neural circuits and numerous chronic diseases that affect the gut-brain axis, including but not limited to inflammatory bowel diseases, metabolic syndrome, visceral pain, and eating disorders (Mayer and Collins, 2002; Powley et al., 2005; Faris et al., 2008; Blackshaw et al., 2010; Cluny et al., 2012; Larauche et al., 2012; Raybould, 2012). The primary goal of this article is to review the principles, advantages, and limitations of various approaches that permit the genetic labeling of specific populations of neurons within the gut-brain axis in temporally and spatially controlled manners. We will focus on components of the vagus and spinal nerves that innervate the gut; however, the methods described in this article can also be applied to other components of the peripheral nervous system (PNS). Further information on the mapping of peripheral nociceptive, somatosensory and somatomotor pathways using reporter mice can be found elsewhere (Tucker et al., 2001; Nguyen et al., 2002; Basbaum and Braz, 2010; Li et al., 2011; Whitney et al., 2011). Although this article focuses on the anatomy of the adult gut-brain axis (rather than its physiology), the usefulness of transgenic tools in studying the metabolic functions of the gut-brain axis will be briefly discussed in the last section.

\section{LABELING GUT-BRAIN AXIS NEURONS WITH TRANSGENIC TECHNOLOGIES SURROGATE REPORTERS \\ Principle, advantages, and limitations}

Several mouse models that express fluorescent reporter proteins in subsets of gut-brain axis neurons have been described in the literature (Table 1). These mice generally possess a transgene incorporating the regulatory elements of a gene endogenously 
Table 1 | Non-exhaustive list of the genetic models employed to introduce reporter expression in the rodent gut-brain axis.

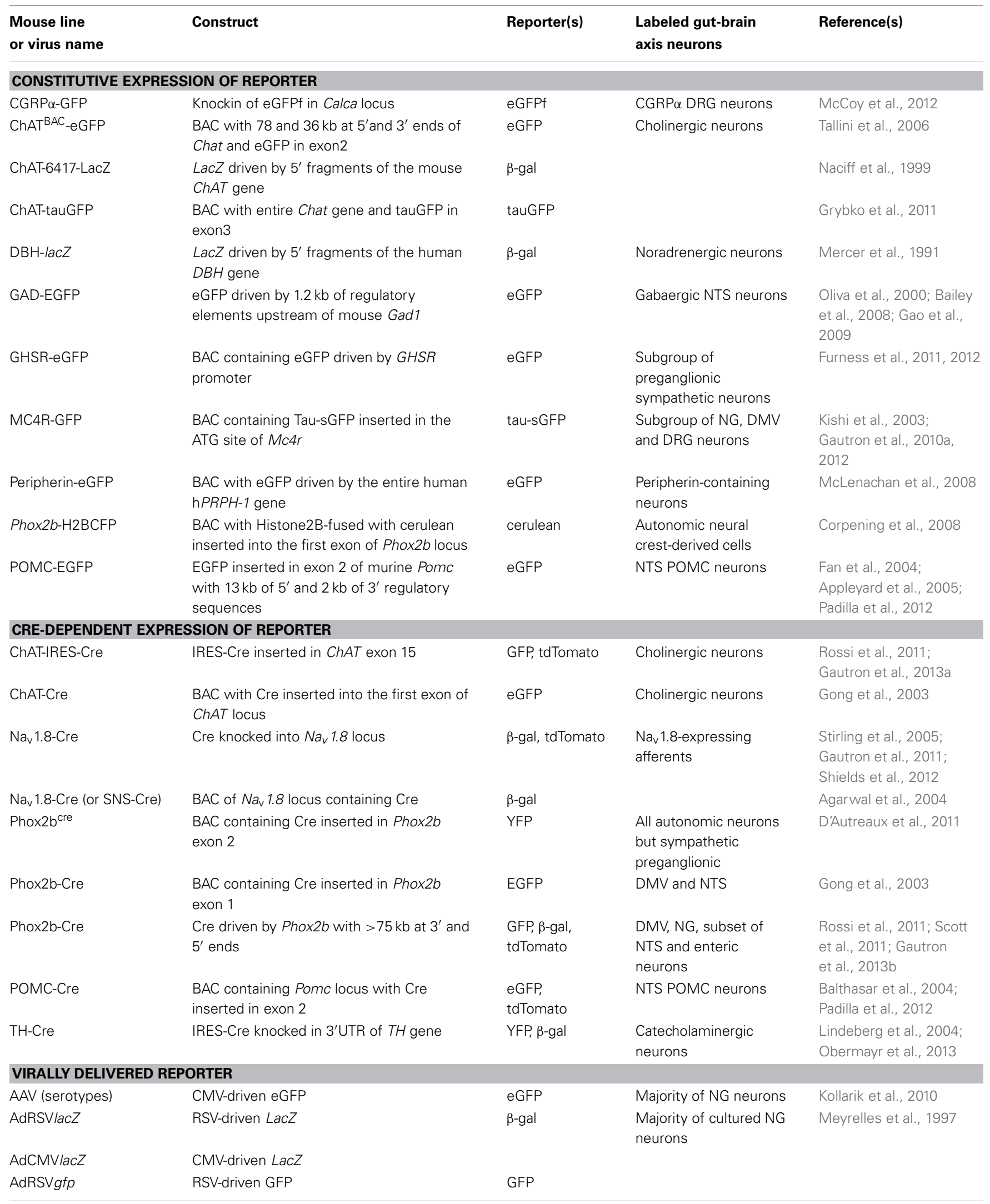


Table 1 | Continued

\begin{tabular}{|c|c|c|c|c|}
\hline $\begin{array}{l}\text { Mouse line } \\
\text { or virus name }\end{array}$ & Construct & Reporter(s) & $\begin{array}{l}\text { Labeled gut-brain } \\
\text { axis neurons }\end{array}$ & Reference(s) \\
\hline PRSx8-AlstR-eGFP-LV & eGFP driven by Phox 2 b-activated promoter & eGFP & $\begin{array}{l}\text { DMV neurons at site of } \\
\text { injection }\end{array}$ & Mastitskaya et al., 2012 \\
\hline PRSx8-ChIEFtdTomato-AV & $\begin{array}{l}\text { tdTomato driven by Phox } 2 \text { b-activated } \\
\text { promoter }\end{array}$ & tdTomato & & \\
\hline rAAV8-GFP & CMV-driven GFP & GFP & $\begin{array}{l}\text { Subgroup of DRG } \\
\text { neurons innervating the } \\
\text { colon }\end{array}$ & $\begin{array}{l}\text { Storek et al., 2008; } \\
\text { Vulchanova et al., 2010; } \\
\text { Schuster et al., } 2013\end{array}$ \\
\hline
\end{tabular}

For abbreviations and references, see the text.

expressed in gut-brain axis neurons and a green fluorescent protein (GFP) gene or one of its variants. Different approaches for inserting a transgene into the genome exist, but most of the mice discussed in this article were generated either using bacterial artificial chromosome (BAC transgene) or knock-in (inserted in the endogenous allele) approaches. Both approaches have advantages and issues, which are described in more specialized articles (Gong et al., 2003; Dhaliwal and Lagace, 2011; Heffner et al., 2012; Murray et al., 2012). Nonetheless, it is important to remember that the insertion of a transgene into the genome with the $\mathrm{BAC}$ approach is random. Due to this random insertion, transgene expression does not always perfectly recapitulate that of the endogenous gene. In contrast, the knock-in approach produces reporter expression that is under the control of endogenous regulatory sequences, which results faithful expression patterns. In all cases, ectopic transgene expression can occur, and the distribution of the reporter must be systematically compared to that of the endogenous gene of interest.

GFP is a widely used fluorescent reporter that is welltransported and allows for the labeling of terminal endings in both the periphery and CNS. In addition, constitutive reporters closely reflect the endogenous expression of one particular gene of interest at any given time and can allow for the labeling of cells that are otherwise difficult to detect using conventional anatomical methods (Padilla et al., 2012). GFP reporters, however, are not without caveats. For instance, GFP is not always bright enough to be observed without immunostaining (Liu et al., 2003). Fortunately, antisera against GFP that can be used to stain GFP-containing structures are widely available. The marking of cells with GFP reporters is not permanent, and, consequently, these reporters can be useful in studies that aim to examine dynamically regulated proteins (via the resulting up- or downregulation of GFP). However, this feature can also be a drawback if the primary goal of the study is fate mapping or the permanent labeling of a group of neurons across physiological circumstances. Finally, GFP has been reported to be potentially toxic to brain cells at high expression levels (Howard et al., 2008). Although it does not have the versatility of fluorescent reporters, another reporter protein commonly employed in molecular biology is the $\beta$-galactosidase enzyme, which is encoded by the lac $Z$ gene. Cells expressing lac $Z$ can be labeled in straightforward manner with a blue dye.

\section{Review of available tools}

The choline acetyltransferase (ChAT) gene encodes the enzyme necessary for the synthesis of acetylcholine, the principal neurotransmitter of preganglionic parasympathetic and sympathetic neurons and a large proportion of enteric neurons (Arvidsson et al., 1997). A transgenic mouse with lacZ expression that is restricted to cholinergic neurons was generated more than a decade ago (Naciff et al., 1999). This study also established the regulatory sequence in the ChAT locus that is necessary to drive specific lac $Z$ expression in cholinergic neurons. Dorsal motor nucleus of the vagus (DMV) neurons have been stained in this mouse, but other gut-brain axis neurons have not been examined. More recently, $\mathrm{ChAT}^{\mathrm{BAC}}$-eGFP and $\mathrm{ChAT}^{\mathrm{BAC}}$-tau-GFP animals were generated using a BAC strategy (Tallini et al., 2006; Grybko et al., 2011). In both lines, the expression of either enhanced GFP (eGFP) or tau-GFP is under the control of the ChAT promoter. Tau is a microtubule-binding protein and, consequently, tau-GFP fusion protein is more effectively transported to terminal processes than GFP alone. As anticipated, the fluorescence in these two lines has been reported in all cholinergic neurons including, DMV and enteric neurons. A study by Grybko and colleagues demonstrated bright native GFP fluorescence that perfectly colocalized with ChAT immunoreactivity. Although these animals have not been characterized in depth (e.g., with ectopic expression), they appear to be useful for the study of cholinergic gut-brain axis neurons.

Melanocortin-4 receptor (MC4R) is an important molecular player in the regulation of feeding, metabolic, and autonomic functions (Cone, 2005). Not surprisingly, MC4R is expressed in gut-brain axis neurons including subsets of both motor and sensory vagal and spinal neurons (Kishi et al., 2003; Gautron et al., 2010a, 2012). MC4R-GFP mice that express tau-sapphireGFP fusion protein under the control of the MC4R regulatory sequences have been generated (Liu et al., 2003) (Figure 2A). These mice express GFP in subgroups of nodose ganglion (NG) and DMV neurons, as well as in preganglionic sympathetic neurons (Liu et al., 2003; Gautron et al., 2010a), and the GFP is present only in MC4R-expressing neurons. Interestingly, GFP is transported to the terminal endings of vagal neurons within the gastrointestinal tract and, hence, reveal the peripheral targets of MC4R in the hepatic artery, myenteric plexus and intestinal mucosa (Gautron et al., 2010a). 


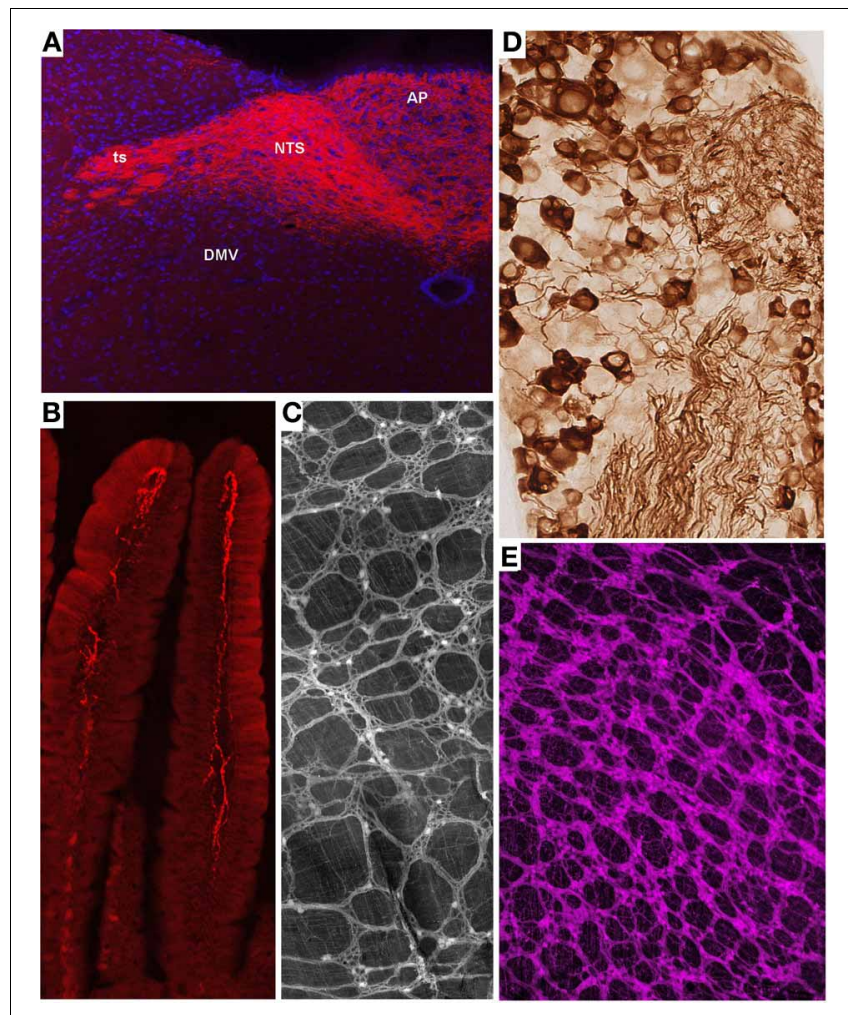

FIGURE 2 | Representative examples of transgenic approaches that enable the marking of restricted gut-brain axis neurons in the mouse. (A) Vagal sensory neurons in the NG of MC4R-GFP mouse stained with an anti-GFP antibody and diaminobenzidine. Notably, both the cell bodies and axons of vagal sensory neurons are clearly labeled. (B,D) Fluorescently labeled terminal fibers in the dorsovagal-complex and duodenum mucosa of a Nav 1.8-Cre-tdTomato mouse. (C) Whole-mount of the ileal myenteric plexus of a Phox $2 \mathrm{~b}$-Cre-tdTomato mouse revealing vagal extrinsic innervation and isolated innervation of enteric neurons. (E) Whole-mount of the gastric myenteric plexus of a ChAT-Cre-tdTomato mouse containing fluorescent preganglionic fibers intermingled with cholinergic enteric neurons that reveals the myenteric plexus. The above images are all unpublished and were generated in our laboratory using mouse lines described in the article.

A mouse that expresses eGFP under the ghrelin receptor (GHSR) promoter was recently characterized (Furness et al., 2011). Simply expressed, ghrelin is a hormone secreted by the stomach epithelium that promotes hunger and modulates autonomic functions (Nogueiras et al., 2008). Using double-labeling and retrograde tracer experiments, a subgroup of preganglionic sympathetic neurons, including neurons connected to the gut (as evidenced by retrograde tracing experiments), has been identified to contain eGFP (Furness et al., 2012). The projections of these neurons terminating in sympathetic ganglia are nicely labeled by eGFP immunohistochemistry. These data suggest that GHSR-eGFP mice are a valid model for identifying GHSR-expressing gut-brain axis neurons. As GHSR mRNA has been reported to be present in NG and DMV neurons (Date et al., 2002; Zigman et al., 2006), further work to determine whether vagal neurons are labeled in this reporter model is warranted.
GABAergic interneurons located in the nucleus of solitary tract (NTS) play a critical role in vago-vagal reflexes (Bailey et al., 2008). GAD-EGFP mice express eGFP under the control of the glutamic acid decarboxylase-67 gene (aka Gad1) (Oliva et al., 2000). The vast majority of GFP-positive cells are immunoreactive for GABAergic markers. Many brain sites known to contain GABAergic neurons do not display GFP fluorescence, which suggests GFP underexpression. Brainstem slices from the GAD-EGFP mouse have been employed to facilitate the patch-clamping of interneurons in the dorsovagal complex to conduct detailed measurements of their electrophysiological properties in response to vagal afferent stimulation (Bailey et al., 2008; Gao et al., 2009).

Paired-like homeobox 2b (Phox $2 \mathrm{~b}$ ) is a transcription factor that is critically involved in the early differentiation of autonomic and viscerosensory pathways (Brunet and Pattyn, 2002). The neural precursors of many gut-brain axis neurons express Phox $2 \mathrm{~b}$ during development including virtually all parasympathetic, enteric and sympathetic ganglia neurons (Tiveron et al., 1996). One mouse line expressing a fused Histone2B-cerulean protein under the control of Phox $2 b$ was generated using a BAC strategy to mark enteric progenitors (Corpening et al., 2008). The reporter strictly localizes to the nucleus, rendering the identification of adjacent neurons straightforward. Expression of this transgene has been demonstrated in Phox2b cells in the CNS, sympathetic chain and enteric system, which agrees with the known distribution of Phox $2 b$. However, it is not clear whether vagal neurons express the transgene. Double-labeling with an antibody against Phox $2 \mathrm{~b}$ further validated the genuine distribution of the transgene in Phox2b cells in the developing and adult gut. Thus, far, this model has primarily been used to monitor the migration of enteric progenitors in the developing murine gut and to identify adult neural crest derived cells (Corpening et al., 2008).

Proopiomelanocortin (POMC) is a precursor of several pituitary and hypothalamic peptides that is important in neuroendocrine and metabolic functions (Liu et al., 1992; Cowley et al., 2001). The NTS contains a small population of POMC-expressing neurons (Padilla et al., 2012). Unlike other POMC cells, NTS POMC neurons produce little POMC transcript, rendering their detection challenging with conventional neuroanatomical tools. Fortunately, a mouse expressing eGFP under the control of the regulatory sequence of the murine Pomc gene has been generated and widely used to visualize NTS POMC neurons (Cowley et al., 2001; Fan et al., 2004; Appleyard et al., 2005; Padilla et al., 2012). Specifically, electrophysiological studies using POMC-EGFP animals have identified NTS POMC neurons as part of a vagovagal circuit that is implicated in satiation (Appleyard et al., 2005).

Other GFP reporter lines that are potentially interesting for the study of gut-brain axis neurons include the peripherin-eGFP (McLenachan et al., 2008) and aCGRP-farnesylated-GFP mice (McCoy et al., 2012). Peripherin is an intermediate filament that is not unique to the gut-brain axis but is widely distributed in the PNS (Troy et al., 1990). The peripherin-eGFP mouse shows fluorescence in many peripheral sensory neurons and enteric neurons and their peripheral projections (McLenachan et al., 2008). It remains unclear whether GFP expression recapitulates endogenous peripherin gene expression. Calcitonin gene-related 
peptide (CGRP)- $\alpha$ and $-\beta$ are neuropeptides produced in enteric, nociceptive and viscerosensory neurons (Mulderry et al., 1988). The CGRP $\alpha$-GFP mouse shows GFP immunoreactivity in many dorsal root ganglion (DRG) neurons and nerve bundles in the intestines but not in enteric neurons (McCoy et al., 2012). While all CGRP-immunoreactive DRG neurons display GFP, approximately $30 \%$ of GFP neurons are not CGRP immunoreactive, which raises the question of transgene ectopic expression and/or subthreshold expression of CGRP.

The dopamine $\beta$-hydroxylase $(D B H)$ gene is responsible for the synthesis of noradrenaline in the autonomic nervous system (Elfvin et al., 1993). The human $\beta$-hydroxylase gene has previously been employed to drive $L a c Z$ expression in the mouse to identify noradrenergic neurons (Mercer et al., 1991). Several lines have been produced, including one that expresses $\beta$-gal fused with a nuclear translocation signal. As anticipated, transgene expression has been reported in sympathetic ganglia, cranial parasympathetic ganglia, the enteric nervous system, and in a small portion of neurons in the peripheral sensory ganglia (Mercer et al., 1991). However, the presence of transgene expression in cholinergic ganglia may be due to ectopic expression.

Finally, while the development of the enteric nervous system is a field of study that is too vast to be reviewed in the current article, it is noteworthy that a number of transgenic reporters have been created to study the fate mapping and differentiation of enteric neurons during early development (Hanna et al., 2002; Young et al., 2004; Deal et al., 2006; Corpening et al., 2008, 2011; Mundell et al., 2012). To avoid oversimplifying this complex area of research, we deliberately avoid reviewing these models.

\section{Cre/LoxP TECHNOLOGY}

\section{Principle, advantages, and limitations}

Cre/LoxP technology deserves specific attention, as this approach profoundly changed how neuroanatomy is conceived and performed (Dymecki and Kim, 2007; Livet et al., 2007; Madisen et al., 2010; Weissman et al., 2011). Figure 3 describes the principles of the Cre/LoxP technology applied to the labeling of gut-brain axis neurons. Briefly, by transgenically directing the expression of Cre-recombinase (Cre) to discrete populations of neurons, including gut-brain axis neurons (using BAC or gene targeting), it is possible to induce and modulate the expression of a target fluorescent reporter in a Cre-responsive manner. Recently, different laboratories have taken advantage of available mouse Cre lines to specifically manipulate gene expression in autonomic neurons. To label neurons, select Cre mice can be systematically crossed with reporter mice that possess a loxP-flanked stop cassette that prevents the expression of $L a c Z$ or a fluorescent reporter protein. In Cre-expressing neurons, however, the transcriptional termination sequence is excised allowing reporter production (Madisen et al., 2010). As an example, mice that express tdTomato in a Cre-dependent manner are often utilized because tdTomato is one of the brightest red fluorescent proteins available (Shaner et al., 2004). Thus, native fluorescence can be observed not only in the cell bodies but also the central relays and peripheral endings, which reveals the full extent of Cre-expressing neuron connectivity. One major advantage of this approach is that it allows for the permanent labeling of non-replicating cells with a

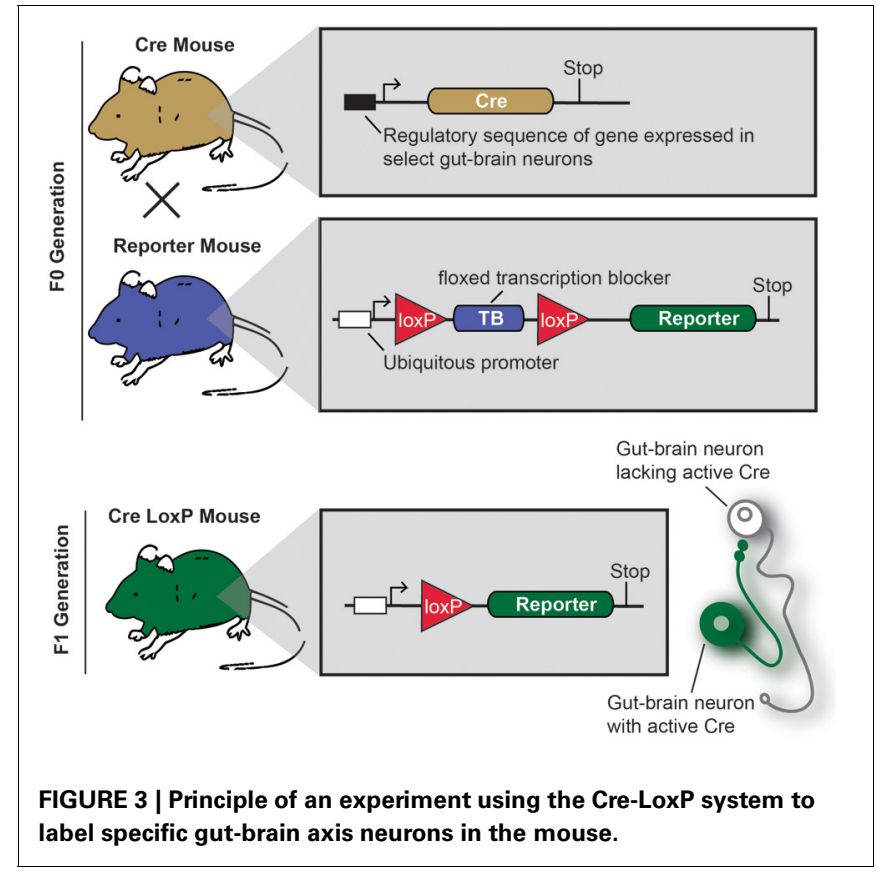

reporter protein. A few examples the utilization of the aforementioned strategy of labeling gut-brain axis neurons are described below (see also Table 1). Nonetheless, caution must be taken when interpreting the distribution of any given Cre-expressing cell population. Indeed, Cre expression can occur transiently in developing neurons that do not express the transgene of interest in adulthood, which results in the labeling of cells other than the intended target neurons (Heffner et al., 2012; Padilla et al., 2012). Thus, off-target and inconsistent Cre activity must be considered as potential drawbacks when using the Cre-LoxP approach.

\section{Review of available tools}

$\mathrm{Na}_{\mathrm{v}} 1.8$ is a tetrodotoxin-resistant sodium voltage-gated channel that is enriched in C-fiber peripheral afferents, including a significant proportion of spinal nociceptors, and subsets of low-threshold mechanoreceptors (Djouhri et al., 2003; Fukuoka et al., 2008; Shields et al., 2012). It has been clearly established that $\mathrm{Na}_{\mathrm{v}} 1.8$ is essential to the electrogenesis of nociceptors and, as a corollary, certain pain phenotypes including visceral pain (Laird et al., 2002; Zimmermann et al., 2007). More surprisingly, expression of $\mathrm{Na}_{\mathrm{v}} 1.8$ has been demonstrated in a majority of vagal sensory neurons (Stirling et al., 2005; Gautron et al., 2012). Transgenic mice expressing Cre under the control of the $\mathrm{Na}_{\mathrm{v}} 1.8$ promoter have been generated and characterized (Stirling et al., 2005). In these mice, the translational start-site of $\mathrm{Na}_{\mathrm{v}} 1.8$ was substituted with that of Cre recombinase. Mice carrying one $\mathrm{Na}_{\mathrm{v}} 1.8$-cre allele show normal pain behavior, and their DRG neurons exhibit normal electrophysiological properties (Stirling et al., 2005). However, mice with two Cre alleles are equivalent to $\mathrm{Na}_{\mathrm{v}} 1.8$ knock-out mice and, thus, tetrodotoxin-sensitive currents are absent in these mice. Embryonic and adult Cre recombinase expression reported by $\beta$-galactosidase activity is specific to small diameter neurons in 
the DRG and trigeminal ganglion and many neurons in the NG. Other than a few neurons in the superior cervical ganglion, no Cre activity has been observed in peripheral tissues or the CNS. We, and others, crossed $\mathrm{Na}_{\mathrm{v}} 1.8$-Cre mice with tdTomato reporter animals (Gautron et al., 2011; Shields et al., 2012). In the offspring, all $\mathrm{Na}_{\mathrm{v}} 1.8$-expressing neurons, including many vagal and spinal afferents and their connections within the gut and CNS, are fluorescently marked (Gautron et al., 2011). As with other examples, we were able to visualize vagal tension and mucosal endings in the myenteric plexuses of $\mathrm{Na}_{\mathrm{v}} 1.8-\mathrm{Cre}$ tdTomato mice (Figures 2B,D). Importantly, the numbers and distribution patterns of tdTomato-positive cells in the DRG and NG are directly comparable to those of $\mathrm{Na}_{\mathrm{v}} 1.8 \mathrm{mRNA}$, suggesting that Cre activity occurs only in $\mathrm{Na}_{\mathrm{v}} 1.8$-expressing neurons. Another mouse expressing Cre under the $\mathrm{Na}_{\mathrm{v}} 1.8$ promoter also exists (Agarwal et al., 2004). Because this model was generated with a BAC, it has the advantage of not disrupting the endogenous $N a_{v} 1.8$ gene in contrast to the knock-in approach described previously.

ChAT-Cre mice have recently been generated by targeting the ChAT gene with IRES-Cre (Rossi et al., 2011). Double-labeling experiments have shown that these mice faithfully express Cre in cholinergic neurons both in the CNS and PNS. When crossed with a tdTomato reporter line, the offspring produce tdTomato in all cholinergic neurons, which allows for distinct labeling of the cell bodies and projections of all preganglionic sympathetic and parasympathetic neurons and cholinergic enteric neurons (Gautron et al., 2013a) (Figure 2C). Importantly, Cre activity appears to be limited to ChAT-immunoreactive cells. Compared to the ChAT-GFP lines described previously, ChAT-Cre mice offer the advantage of allowing the reporter to be invariably expressed in ChAT cells regardless of ChAT expression levels. This is important because neuronal ChAT mRNA levels may be differentially regulated under different physiological circumstances (Gibbs, 1996; Castell et al., 2002). Several mouse lines expressing Cre under the control of ChAT have also been created in the context of the Gensat project (Gong et al., 2003). These mice appear to show restricted Cre activity in cholinergic neurons including DMV neurons. Little information is available about the distribution of Cre in other gut-brain axis neurons.

A mouse expressing Cre under the control of Pomc regulatory elements has been generated with a BAC (Balthasar et al., 2004). POMC-Cre mice crossed with different inducible reporters have been used in several laboratories to identify POMC hypothalamic and/or NTS neurons (Balthasar et al., 2004; Huo et al., 2006; Zheng et al., 2010). A recent study revealed significant discrepancies between cells with POMC-Cre activity and POMC-EGFP transgene expression (Padilla et al., 2012). Specifically, the populations of NTS cells labeled by the coexpression of both the POMC-EGFP and POMC-Cre overlap minimally, which raises again the issue of possible ectopic and off-target expression.

Several Phox 2b-Cre mice have recently been generated by different laboratories (D'Autreaux et al., 2011; Rossi et al., 2011). Phox 2b-Cre mice from the group of Dr. Brunet were crossed with a YFP reporter mouse to label Phox $2 \mathrm{~b}$-Cre-expressing neurons (D'Autreaux et al., 2011). As a result, Phox $2 b^{\text {CreYFP }}$ embryos show YFP staining in the progenitors of many neurons of the
AP, NTS, DMV, NG, and the enteric nervous system. Phox2bCre mice created by the Gensat project display Cre activity in the NTS and DMV (Gong et al., 2003). The extent to which this mouse exhibits Cre in peripheral ganglia is unknown. The Phox $2 b-C r e$ line generated by the Elmquist group was crossed with a GFP or lacZ reporter mouse and proven to express Cre in all NG, DMV, and a subgroup of NTS neurons (Rossi et al., 2011; Scott et al., 2011). The latter mouse did not display Cre activity in sympathetic neurons and displayed Cre activity in only a small subset of enteric neurons, suggesting that, presumably due to positional effects, the expression of Cre underestimates that of the endogenous Phox $2 b$ gene. Nonetheless, this mouse has proven useful for selectively tagging the vagus nerve. In

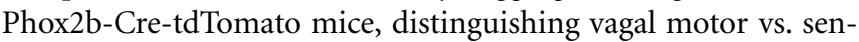
sory endings remains difficult in locations in which they are intermingled (i.e., the myenteric plexus); however, the anatomical integrity of the entire vagus nerve can easily be gauged (Gautron et al., 2013b) (Figure 2E). In the latter study, we also showed that Roux-en-Y gastric bypass surgery results in significant vagal denervation of the stomachs of Phox2b-Cre-tdTomato mice. This finding is in agreement with observations that suggest significant morphological and electrophysiological changes in vagal neurons following gastrointestinal surgical intervention in the rat (Phillips and Powley, 2005; Guijarro et al., 2007; Browning et al., 2013b).

Postganglionic sympathetic neurons express tyrosine hydroxylase $(\mathrm{TH})$, the rate-limiting enzyme in catecholamine biosynthesis (Elfvin et al., 1993). Several mice expressing Cre under the control of the TH promoter have been generated in the past (Gelman et al., 2003; Lindeberg et al., 2004; Savitt et al., 2005). Using a TH-Cre knock-in, catecholaminergic gut-brain axis neurons, including sympathetic postganglionic neurons and a small population of enteric neurons transiently expressing $\mathrm{TH}$ during development, can be marked (Lindeberg et al., 2004; Obermayr et al., 2013). The patterns of Cre activity have been validated using TH staining, Cre mRNA in situ hybridization and reporter distributions ( $\beta$-gal and YFP).

Remarkably, numerous reagents expressing Cre under the control of transcription factors implicated in the development of neural-crest derived tissues (other than Phox $2 b$ ) are available (Druckenbrod and Epstein, 2005; Stine et al., 2009; Mundell et al., 2012). While these models are indispensable for tracking enteric progenitors migrating in the developing gut, as mentioned before, it is beyond the scope of this article to review the transgenic tools used in developmental biology. Lastly, new Cre lines are continuously being generated and are readily available to investigators. A few examples include neuropeptide Y-, Transient receptor potential vanilloid receptor 1-, TH-, advilin- and peripherin-Cre mice, which have all been demonstrated to induce Cre expression in populations of peripheral afferents and/or brain neurons (Zhou et al., 2002; Gelman et al., 2003; Braz and Basbaum, 2009; Mishra et al., 2011; Zurborg et al., 2011). While the genes employed to drive Cre expression in the latter transgenics are known to be transcriptionally active in gut-brain axis neurons, insufficient information is available to assess their usefulness in targeting the gut-brain axis. Therefore, we will not include these animals in our review. 


\section{VIRALLY MEDIATED GENE DELIVERY \\ Principles, advantages, and limitations}

Stereotaxic injections of viral vectors of varying packaging capacity, capsid serotype, and cellular tropism are commonly used to deliver transgenes that encode fluorescent proteins into the CNS (Klein et al., 2002; Tenenbaum et al., 2004; Luo et al., 2008; Betley and Sternson, 2011). As illustrated by the examples below, viral vectors appear adequate to transfer GFP expression in gutbrain axis neurons; however, few studies have attempted to do this (Table 1). Generally speaking, viral vectors confer long-term gene expression and are deliverable to laboratory rodents, nonhuman primates and to humans for therapeutic purposes (Kay et al., 2000; Christine et al., 2009; Bu et al., 2012). While immune responses to viral particles and toxicity are a concern with certain viral vectors (Sawada et al., 2010), recombinant adeno-associated viruses (rAAV) produce little (if any) inflammation (Chamberlin and Saper, 1998; Lowenstein and Castro, 2002), and virally delivered transgenes do not integrate into the host genome (Schnepp et al., 2003). To further minimize neuronal injury, using a glass micropipette coupled to an iontophoretic or air-pressure set-up for injection is preferable (Chamberlin et al., 1998; Krenzer et al., 2011). Interestingly, transgenes transferred by viral vectors can be Cre-dependent, which allows specific gene expression that is limited to molecularly defined neurons at the site of injection (Lazarus et al., 2007; Gautron et al., 2010b; Harris et al., 2012). However, this strategy is inherently limited by the fact that injecting the NG, DRG, or enteric system is technically challenging. Finally, the number of transfected neurons at the site of injection is always inherently variable, and it is not completely clear whether all gut-brain axis neurons are equally sensitive to viral transfection.

\section{Review of available tools}

Mastitskaya and colleagues recently demonstrated the feasibility of delivering a few different transgenes encoding engineered receptors (i.e., allatostatin and channel rhodopsin receptors) into the rat DMV using a lentivirus and an adenovirus (Mastitskaya et al., 2012). Of note, both vectors incorporated an artificial Phox2 promoter to ensure the preferential expression of the transgenes in the DMV. Each transgene was also coupled with the expression of a specific fluorescent reporter, either eGFP or tdTomato. As a result, DMV neurons in brainstem slices could be visualized by their respective eGFP and tdTomato fluorescence and then patched for electrophysiological recordings. This study is a good illustration of the usefulness of viral vectors in manipulating gene expression in DMV neurons. There are few studies that have attempted virally mediated gene delivery in neurons residing in the peripheral ganglia. Intrathecal delivery of rAAVs carrying a GFP transgene has been performed in rats and mice and resulted in the labeling of DRG neurons (Storek et al., 2008; Vulchanova et al., 2010). Despite the variable transfection efficiency of this approach, it was recently reported that this approach can be used to label subsets of DRG neurons that supply the mouse colon (Schuster et al., 2013). Specifically, GFP-positive spinal sensory terminals have been observed in the colonic myenteric plexus and mucosa of injected mice. Thus, far, only one study has directly administered AAVs of different serotypes into the guinea pig NG (Kollarik et al., 2010). Stable expression of eGFP was successfully obtained in $50-80 \%$ of vagal sensory neurons depending on the serotype. The same study indicated that the injection of an AAV into vagally innervated tissue is sufficient to transfect vagal neurons innervating that tissue (i.e., the esophagus) and that the eGFP-filled terminal endings of transfected vagal sensory neurons can be observed in the periphery including the trachea and esophagus. In the case of vagal sensory neurons, it is also known that a vast majority of primary-cultured dissociated NG neurons can be successfully transfected with adenoviruses driving either LacZ or GFP expression (Meyrelles et al., 1997).

\section{AREAS OF IMPROVEMENT}

Although the rapidly evolving transgenic technologies described in this article are not meant to replace more conventional approaches, they offer numerous advantages over classical tracing and immunohistochemical techniques. In the future, we foresee that the approaches described in this article will change many areas of research that require the visualization of visceral afferents, vagal and enteric neurons, especially for scientists who are not familiar with neuroanatomical techniques. However, transgenic technologies have numerous caveats. First, the paucity of well-characterized mouse lines that permit targeting gut-brain neurons greatly limits our ability to manipulate the full range of the different types of gut-brain axis neurons described in the literature. For example, the development of Cre lines that are adequate to differentiate vagal stretch (intramuscular arrays) vs. tension receptors (intraganglionic laminar endings) from mucosal endings would be useful in clarifying the physiological role of each of the aforementioned vagal endings. It is particularly important considering that subpopulations of vagal afferents may have completely different roles in appetite regulation. Moreover, the ability to differentiate the non-neuronal cells implicated in the normal functioning of the gut-brain axis, such as glial cells and interstitial cells of Cajal, would be useful (McDougal et al., 2011; Powley and Phillips, 2011; Gulbransen and Sharkey, 2012). We expect that this problem will become smaller in the future as the number of strains generated by large-scale Cre-driver projects continues to grow and become available in public repositories (Gong et al., 2003; Murray et al., 2012). The lack of temporal specificity of the models described in this article is another problem. For example, it would be useful to have the ability to restrict Cre to a desired life stage. Among other strategies, this could be achieved using mice that express a Cre-estrogen receptor-fused protein. In these animals, Cre-induced recombination occurs only following the exogenous administration of tamoxifen (Badea et al., 2003), which restricts Cre activity to a desired temporal stage and facilitates cell lineage studies. Likewise, the tetracycline system is a popular technique that is employed to control gene transcription in a reversible and temporally restricted manner (Schonig et al., 2013). More inducible Cre drivers relevant to the gut-brain axis will become available in the future. As mentioned before, ectopic and/or inconsistent transgene expressions are issues that need to be addressed when working with transgenic technologies. Lastly, it must be noted that the physiology of the gut-brain axis has been extensively studied in guinea pigs and rats instead of mice, and 
these species have not been traditionally targeted for transgenics. However, transgenic rats, including rat Cre-lines, are becoming more widely available (Witten et al., 2011; Schonig et al., 2012).

\section{PERSPECTIVES IN METABOLIC RESEARCH}

Many investigators acknowledge that identifying the mechanisms and pathways underlying the central integration of visceral information is a true challenge that could provide a better understanding of diseases including obesity (Powley et al., 2005; Berthoud, 2008; Yi and Tschop, 2012). The lack of adequate methods to interrogate neural pathways linking the gut and the brain has largely contributed to the slow progress in this area-especially compared to other areas of sensory biology and somatomotor systems. To aid the investigation of these pathways, we and others have begun using and developing new transgenic tools to manipulate gene expression in the gut-brain axis. In the last section, we will briefly review what is known about the implications of gut-brain axis neurons in diabetes and obesity and will make the case that transgenic models can be instrumental in deciphering the role played by the gut-brain axis in chronic metabolic diseases.

Although hepatic glucose flux is primarily under the direct control of insulin (Cardin et al., 2002), numerous studies have found that stimulating vagal efferents alters peripheral glucose flux and insulin secretion (Shimazu and Fujimoto, 1971; Shimazu, 1971; Rohner-Jeanrenaud et al., 1983; Berthoud et al., 1990; Rozman and Bunc, 2004; Peitl et al., 2005). Moreover, intact vagal fibers and capsaicin-sensitive afferents are required for the normal regulation of hepatic and pancreatic functions (Obici et al., 2001; Pocai et al., 2005; Razavi et al., 2006; Uno et al., 2006; Gram et al., 2007) and the anti-diabetic effects of gastric bypass (Troy et al., 2008). Together, these observations strongly support the idea that gut-brain axis neurons significantly contribute to regulating glucose homeostasis. Furthermore, diabetes is a leading cause of injury to the PNS (Westerman et al., 1989; Drel et al., 2006), and these injuries may profoundly alter the functioning of gut-brain axis as suggested by the many gastrointestinal and autonomic symptoms encountered by people with diabetes. Manipulating the neurons that supply the viscera has also been proposed as a potentially relevant weight-loss strategy on the basis of the known regulatory effect of vagal afferents on satiation (Powley et al., 2005). Subdiaphragmatic vagotomy disrupts food consumption in rodents (Phillips and Powley, 1998; Powley et al., 2005) and induces weight-loss in humans (Kral, 1978), but the results of this procedure are difficult to interpret because vagotomy also impairs gastrointestinal motility. In lean animals, most studies agree that the selective surgical, genetic, or capsaicininduced deafferentation of the vagus nerve results in altered meal patterns (Chavez et al., 1997; Schwartz et al., 1999; Fox et al., 2001; Chi et al., 2004) without causing frank obesity or long-term hyperphagia due to compensatory changes in feeding behavior. In obese animals, however, capsaicin-induced deafferentation of the truncal vagus nerve partially prevents diet-induced obesity (Stearns et al., 2012). Lastly, device-assisted stimulations of the vagus nerve and stomach wall have entered preclinical trials for the treatment of obesity (Aronne and Waitman, 2004; Bodenlos et al., 2007; Camilleri et al., 2008; Val-Laillet et al., 2010), and several laboratories are currently examining the contributions of the different branches of the vagus nerve to the beneficial effects of bariatric surgeries (Bueter et al., 2010; Breen et al., 2012; Shin et al., 2012).

While the above observations taken together link the gut-brain axis to diabetes and obesity, we do not yet possess a clear picture of the contributions of the visceral nerves to the pathophysiologies of chronic metabolic diseases because vagotomy studies have generated confounding results and remain inherently limited in terms of manipulating specific population of vagal afferents. As the vagus nerve is a mixed nerve, surgical techniques, in addition to being technically challenging, also result in full or partial loss of efferent (motor) function. Pharmacological techniques, including the administration of capsaicin to destroy small-diameter sensory neurons, have been used. However, this method also kills some neurons in the CNS without killing all vagal sensory neurons (Ritter and Dinh, 1992; Czaja et al., 2008; Browning et al., 2013a). Additionally, by 60-days post-capsaicin treatment, neuronal nuclei in the NG of rats are not different from controls (Czaja et al., 2008), which limits the applicability of this approach for studying long-term regulation by the sensory vagus nerve. Furthermore, regeneration/plasticity of some sensory terminals after vagotomy has been reported (Phillips et al., 2000). Newly developed genetic tools have emerged to circumvent many of the aforementioned problems. First, transgenic reagents can be particularly useful in studies seeking to knock-out or "reactivate" genes in autonomic pathways relevant to the regulation of peripheral glucose flux and insulin secretion. For example, a few recent studies have employed Cre-LoxP technology to selectively reactivate MC4R expression in preganglionic vagal and sympathetic neurons and demonstrated the key role of this receptor in ameliorating diabetes in MC4R null mice (Rossi et al., 2011; Zechner et al., 2012). Other studies have focused on examining deficits in neurotrophic factor innervation of the gastrointestinal tracts of knockout mice and the physiological consequences of these deficits on feeding (Rossi et al., 2003; Fox, 2013). Second, new neuromodulation techniques have recently been developed that allow the genetic targeting of specific neurons with engineered transmembrane proteins that can exert varied effects on neuronal activity (Aponte et al., 2011; Krashes et al., 2011). Specifically, optogenetic techniques involve light-sensitive proteins known as opsins that alter neuronal activity in response to a blue light. Pharmacogenetic techniques involve G-coupled proteins receptors that only respond to ligands with no other biological activity. While these approaches vary in their kinetics and invasiveness, they both allow the reversible and "remote" control of depolarization or hyperpolarization of targeted neurons within intact neural circuits. To the best of our knowledge, only one study has employed these new strategies to modulate the activity of DMV neurons (Mastitskaya et al., 2012). While this study aimed to interrogate the cardiovascular functions of DMV neurons rather than gut-related functions, it did provide a proof-of-concept experiment demonstrating that opto- and pharmacogenetics have the potential to deeply transform the study of the gut-brain axis. Finally, Cre-LoxP can be used to ablate selective neurons in the CNS or PNS using an inducible diphtheria toxin system (Luquet et al., 2005; Abrahamsen et al., 2008). In the future, these methods 
could be applied to the gut-brain axis to perform "molecular vagotomies" of specific population of vagal neurons.

The above considerations are meant only to illustrate how transgenic tools can be useful to further our understanding and to predict the beneficial and deleterious consequences of gut-brain axis activity modulation by surgical, pharmacological, or deviceassisted means. As the number of transgenic reagents available to gut-brain axis scientists continues to grow and become more sophisticated, we predictable that these new tools will play a critical role in the advancement of our knowledge of the development, morphological plasticity, molecular phenotyping, and connectivity of the healthy and diseased gut-brain axis. In addition to performing neuroanatomy, one can easily imagine many applications for these transgenic tools, including, but not limited

\section{REFERENCES}

Abrahamsen, B., Zhao, J., Asante, C. O., Cendan, C. M., Marsh, S., Martinez-Barbera, J. P., et al. (2008). The cell and molecular basis of mechanical, cold, and inflammatory pain. Science 321, 702-705. doi: 10.1126/science. 1156916

Ackerknecht, E. H. (1974). The history of the discovery of the vegatative (autonomic) nervous system. Med. Hist. 18, 1-8. doi: 10.1017/S0025727300019189

Agarwal, N., Offermanns, S., and Kuner, R. (2004). Conditional gene deletion in primary nociceptive neurons of trigeminal ganglia and dorsal root ganglia. Genesis 38, 122-129. doi: 10.1002/gene.20010

Altschuler, S. M., Bao, X. M., Bieger, D., Hopkins, D. A., and Miselis, R. R. (1989). Viscerotopic representation of the upper alimentary tract in the rat: sensory ganglia and nuclei of the solitary and spinal trigeminal tracts. J. Comp. Neurol. 283, 248-268. doi: $10.1002 / \mathrm{cne} .902830207$

Andersson, U., and Tracey, K. J. (2011). Molecular basis of applied biological therapeutics. J. Intern. Med. 269, 2-7. doi: 10.1111/j.1365-2796.2010.02320.x

Anlauf, M., Schafer, M. K., Eiden, L., and Weihe, E. (2003). Chemical coding of the human gastrointestinal nervous system: cholinergic, VIPergic, and catecholaminergic phenotypes. J. Comp. Neurol. 459, 90-111. doi: 10.1002/cne.10599

Aponte, Y., Atasoy, D., and Sternson, S. M. (2011). AGRP neurons are sufficient to orchestrate feeding behavior rapidly and without training. Nat. Neurosci. 14, 351-355. doi: 10.1038/nn.2739

Appleyard, S. M., Bailey, T. W., Doyle, M. W., Jin, Y. H., Smart, J. L., Low, M. J., et al. (2005). Proopiomelanocortin neurons in nucleus tractus solitarius are activated by visceral afferents: regulation by cholecystokinin and opioids. J. Neurosci. 25, 3578-3585. doi: 10.1523/JNEUROSCI.4177-04.2005

Aronne, L. J., and Waitman, J. A. (2004). Gastric pacing is not enough: additional measures for an effective obesity treatment program. Obes. Surg. 14(Suppl. 1), S23-S27. doi: 10.1381/0960892041978980

Arvidsson, U., Riedl, M., Elde, R., and Meister, B. (1997). Vesicular acetylcholine transporter (VAChT) protein: a novel and unique marker for cholinergic neurons in the central and peripheral nervous systems. J. Comp. Neurol. 378, 454-467.

Auerbach, L. (1863). Ueber einen Jahresberichte der schlesischen Gesellschaft für vaterländische Kultur 40, 103-104.

Badea, T. C., Wang, Y., and Nathans, J. (2003). A noninvasive genetic/pharmacologic strategy for visualizing cell morphology and clonal relationships in the mouse. J. Neurosci. 23, 2314-2322.

Bailey, T. W., Appleyard, S. M., Jin, Y. H., and Andresen, M. C. (2008). Organization and properties of GABAergic neurons in solitary tract nucleus (NTS). J. Neurophysiol. 99, 1712-1722. doi: 10.1152/jn.00038.2008

Balthasar, N., Coppari, R., McMinn, J., Liu, S. M., Lee, C. E., Tang, V., et al. (2004). Leptin receptor signaling in POMC neurons is required for normal body weight homeostasis. Neuron 42, 983-991. doi: 10.1016/j.neuron.2004.06.004 "Transgenic mouse models for the tracing of "Pain" pathways." in Translational Pain Research: From Mouse to Man, eds L. kruger and A. R. Light (Boca Raton, FL: CRC Press), 1-17. Plexus gangliosus myogastricus.

Basbaum, A. I., and Braz, J. M. (2010).

to, patch clamp (Bailey et al., 2008; Gao et al., 2009) and flow cytometry sorting (Buehler et al., 2012) of fluorescently tagged neurons. Obviously, research on gut-brain axis neurons is not limited to metabolic diseases but is pertinent to numerous questions relevant to visceral pain, gut flora homeostasis, whole-body inflammation and eating disorders, among other examples (Faris et al., 2008; Andersson and Tracey, 2011; Sharkey and Mawe, 2012). In summary, the rapidly evolving techniques described in this article have become indispensable and empowered both anatomists and physiologists with unique tools to understand better the gut-brain axis in the context of intact animals.

\section{ACKNOWLEDGMENTS}

I thank Dr. Chen Liu (UTSW) for discussions.

Bellier, J. P., and Kimura, H. (2011). Peripheral type of choline acetyltransferase: biological and evolutionary implications for novel mechanisms in cholinergic system. J. Chem. Neuroanat. 42, 225-235. doi: 10.1016/j.jchemneu. 2011.02.005

Berthoud, H. R. (2008). The vagus nerve, food intake and obesity. Regul. Pept. 149, 15-25. doi: 10.1016/j.regpep.2007.08.024

Berthoud, H. R., Blackshaw, L. A., Brookes, S. J., and Grundy, D. (2004). Neuroanatomy of extrinsic afferents supplying the gastrointestinal tract. Neurogastroenterol. Motil. 16(Suppl. 1), 28-33. doi: $\quad 10.1111 / \mathrm{j} .1743-3150.2004$. 00471.x

Berthoud, H. R., Carlson, N. R., and Powley, T. L. (1991). Topography of efferent vagal innervation of the rat gastrointestinal tract. Am. J. Physiol. 260, R200-R207.

Berthoud, H. R., Fox, E. A., and Neuhuber, W. L. (2006). Vagaries of adipose tissue innervation. Am. J. Physiol. Regul. Integr. Comp. Physiol. 291, R1240-R1242.

Berthoud, H. R., Fox, E. A., and Powley, T. L. (1990). Localization of vagal preganglionics that stimulate insulin and glucagon secretion. Am. J. Physiol. 258, R160-R168.

Berthoud, H. R., and Powley, T. L. (1993). Characterization of vagal innervation to the rat celiac, suprarenal and mesenteric ganglia. J. Auton. Nerv. Syst. 42, 153-169. doi: 10.1016/0165-1838 (93)90046-W

Bertrand, P. P. (2009). The cornucopia of intestinal chemosensory transduction. Front. Neurosci. 3:48. doi: 10.3389/neuro.21.003.2009

Betley, J. N., and Sternson, S. M. (2011). Adeno-associated viral vectors for mapping, monitoring, and manipulating neural circuits.
Hum. Gene Ther. 22, 669-677. doi: 10.1089/hum.2010.204

Blackshaw, L. A., Brierley, S. M., and Hughes, P. A. (2010). TRP channels: new targets for visceral pain. Gut 59, 126-135. doi: 10.1136/gut.2009.179523

Bodenlos, J. S., Kose, S., Borckardt, J. J., Nahas, Z., Shaw, D., O’Neil, P. M., et al. (2007). Vagus nerve stimulation acutely alters food craving in adults with depression. Appetite 48, 145-153. doi: 10.1016/j.appet.2006.07.080

Braz, J. M., and Basbaum, A. I. (2009). Triggering geneticallyexpressed transneuronal tracers by peripheral axotomy reveals convergent and segregated sensory neuron-spinal cord connectivity. Neuroscience 163, 1220-1232. doi: 10.1016/j.neuroscience.2009.07.051

Breen, D. M., Rasmussen, B. A., Kokorovic, A., Wang, R., Cheung, G. W., and Lam, T. K. (2012). Jejunal nutrient sensing is required for duodenal-jejunal bypass surgery to rapidly lower glucose concentrations in uncontrolled diabetes. Nat. Med. 18, 950-955. doi: 10.1038/nm.2745

Brierley, S. M. (2010). Molecular basis of mechanosensitivity. Auton. Neurosci. 153, 58-68. doi: 10.1016/j.autneu.2009.07.017

Browning, K. N., Babic, T., Holmes, G. M., Swartz, E., and Travagli, R. A. (2013a). A critical re-evaluation of the specificity of action of perivagal capsaicin. J. Physiol. 591, 1563-1580.

Browning, K., Fortna, S. R., and Hajnal, A. (2013b). Roux-en-Y Gastric Bypass reverses the effects of diet-induced obesity to inhibit the responsiveness of central vagal motoneurones. J. Physiol. 591, 2357-2372.

Brunet, J. F., and Pattyn, A. (2002). Phox2 genes - from patterning 
to connectivity. Curr. Opin. Genet. Dev. 12, 435-440. doi: 10.1016/ S0959-437X(02)00322-2

$\mathrm{Bu}$, J., Ashe, K. M., Bringas, J., Marshall, J., Dodge, J. C., Cabrera-Salazar, M. A., et al. (2012). Merits of combination cortical, subcortical, and cerebellar injections for the treatment of niemann-pick disease type a. Mol. Ther. 20, 1893-1901. doi: $10.1038 / \mathrm{mt} .2012 .118$

Buehler, D. P., Wiese, C. B., Skelton, S. B., and Southard-Smith, E. M. (2012). An optimized procedure for fluorescence-activated cell sorting (FACS) isolation of autonomic neural progenitors from visceral organs of fetal mice. J. Vis. Exp. e4188.

Bueter, M., Lowenstein, C., Ashrafian, H., Hillebrand, J., Bloom, S. R., Olbers, T., et al. (2010). Vagal sparing surgical technique but not stoma size affects body weight loss in rodent model of gastric bypass. Obes. Surg. 20, 616-622. doi: 10.1007/s11695-010-0075-5

Camilleri, M., Toouli, J., Herrera, M. F., Kulseng, B., Kow, L., Pantoja, J. P., et al. (2008). Intra-abdominal vagal blocking (VBLOC therapy): clinical results with a new implantable medical device. Surgery 143, 723-731. doi: 10.1016/j.surg.2008.03.015

Cardin, S., Walmsley, K., Neal, D. W., Williams, P. E., and Cherrington, A. D. (2002). Involvement of the vagus nerves in the regulation of basal hepatic glucose production in conscious dogs. Am. J. Physiol. Endocrinol. Metab. 283, E958-E964.

Castell, X., Diebler, M. F., Tomasi, M., Bigari, C., De Gois, S., Berrard, S., et al. (2002). More than one way to toy with ChAT and VAChT. J. Physiol. Paris 96, 61-72. doi: 10.1016/S0928-4257(01)00081-X

Chamberlin, N. L., Du, B., de Lacalle, S., and Saper, C. B. (1998). Recombinant adenoassociated virus vector: use for transgene expression and anterograde tract tracing in the CNS. Brain Res. 793, 169-175. doi: 10.1016/S0006-8993(98)00169-3

Chamberlin, N. L., and Saper, C. B. (1998). A brainstem network mediating apneic reflexes in the rat. J. Neurosci. 18, 6048-6056.

Chavez, M., Kelly, L., York, D. A., and Berthoud, H. R. (1997). Chemical lesion of visceral afferents causes transient overconsumption of unfamiliar high-fat diets in rats. Am. J. Physiol. 272, R1657-R1663.

Chi, M. M., Fan, G., and Fox, E. A. (2004). Increased short-term food satiation and sensitivity to cholecystokinin in neurotrophin-4 knock-in mice. Am. J. Physiol. Regul. Integr. Comp. Physiol. 287, R1044-R1053.

Chiocchetti, R., Poole, D. P., Kimura, H., Aimi, Y., Robbins, H. L. Castelucci, P., et al. (2003). Evidence that two forms of choline acetyltransferase are differentially expressed in subclasses of enteric neurons. Cell Tissue Res. 311, 11-22. doi: 10.1007/s00441-002-0652-6

Christine, C. W., Starr, P. A., Larson, P. S., Eberling, J. L., Jagust, W. J., Hawkins, R. A., et al. (2009). Safety and tolerability of putaminal AADC gene therapy for Parkinson disease. Neurology 73, 1662-1669. doi: 10.1212/WNL.0b013e3181c29356

Cluny, N. L., Reimer, R. A., and Sharkey, K. A. (2012). Cannabinoid signalling regulates inflammation and energy balance: the importance of the brain-gut axis. Brain Behav. Immun. 26, 691-698. doi: 10.1016/j.bbi.2012.01.004

Cone, R. D. (2005). Anatomy and regulation of the central melanocortin system. Nat. Neurosci. 8, 571-578. doi: $10.1038 / \mathrm{nn} 1455$

Corpening, J. C., Cantrell, V. A., Deal, K. K., and Southard-Smith, E. M. (2008). A Histone2BCerulean BAC transgene identifies differential expression of Phox $2 b$ in migrating enteric neural crest derivatives and enteric glia. Dev. Dyn. 237, 1119-1132. doi: 10.1002/dvdy.21498

Corpening, J. C., Deal, K. K., Cantrell, V. A., Skelton, S. B., Buehler, D. P., and Southard-Smith, E. M. (2011). Isolation and live imaging of enteric progenitors based on Sox10Histone2BVenus transgene expression. Genesis 49, 599-618. doi: 10.1002/dvg.20748

Cowley, M. A., Smart, J. L., Rubinstein, M., Cerdan, M. G., Diano, S., Horvath, T. L., et al. (2001). Leptin activates anorexigenic POMC neurons through a neural network in the arcuate nucleus. Nature 411, 480-484. doi: 10.1038/35078085

Czaja, K., Burns, G. A., and Ritter, R. C. (2008). Capsaicin-induced neuronal death and proliferation of the primary sensory neurons located in the nodose ganglia of adult rats. Neuroscience 154, 621-630. doi: 10.1016/j.neuroscience.2008.03.055

Date, Y., Murakami, N., Toshinai, K., Matsukura, S., Niijima, A., Matsuo, H., et al. (2002). The role of the gastric afferent vagal nerve in ghrelin-induced feeding and growth hormone secretion in rats. Gastroenterology 123, 1120-1128. doi: 10.1053/gast.2002.35954

D’Autreaux, F., Coppola, E., Hirsch, M. R., Birchmeier, C., and Brunet,
J. F. (2011). Homeoprotein Phox $2 b$ commands a somaticto-visceral switch in cranial sensory pathways. Proc. Natl. Acad. Sci. U.S.A. 108, 20018-20023. doi: 10.1073/pnas. 1110416108

Deal, K. K., Cantrell, V. A., Chandler, R. L., Saunders, T. L., Mortlock, D. P., and Southard-Smith, E. M. (2006). Distant regulatory elements in a Sox10-beta GEO BAC transgene are required for expression of Sox 10 in the enteric nervous system and other neural crest-derived tissues. Dev. Dyn. 235, 1413-1432. doi: 10.1002/dvdy.20769

DeFelipe, J. (2010). Cajal's Butterflies of the Soul: Science and Art. Oxford: Oxford University Press.

Dhaliwal, J., and Lagace, D. C. (2011) Visualization and genetic manipulation of adult neurogenesis using transgenic mice. Eur. J. Neurosci. 33, 1025-1036. doi: 10.1111/j.14609568.2011.07600.x

Djouhri, L., Fang, X., Okuse, K., Wood, J. N., Berry, C. M., and Lawson, S. N. (2003). The TTX-resistant sodium channel Nav1.8 (SNS/PN3) expression and correlation with membrane properties in rat nociceptive primary afferent neurons. J. Physiol. (Lond.) 550, 739-752. doi: 10.1113/jphysiol.2003.042127

Drel, V. R., Mashtalir, N., Ilnytska, O., Shin, J., Li, F., Lyzogubov, V. V., et al. (2006). The leptin-deficient (ob/ob) mouse: a new animal model of peripheral neuropathy of type 2 diabetes and obesity. Diabetes 55, 3335-3343. doi: 10.2337/db060885

Druckenbrod, N. R., and Epstein, M L. (2005). The pattern of neural crest advance in the cecum and colon. Dev. Biol. 287, 125-133. doi: 10.1016/j.ydbio.2005.08.040

Dymecki, S. M., and Kim, J. C. (2007) Molecular neuroanatomy's "Three Gs": a primer. Neuron 54, 17-34 doi: 10.1016/j.neuron.2007.03.009

Elfvin, L. G., Lindh, B., and Hokfelt, T. (1993). The chemical neuroanatomy of sympathetic ganglia. Annu. Rev. Neurosci. 16, 471-507. doi: 10.1146/annurev.ne.16.030193. 002351

Fan, W., Ellacott, K. L., Halatchev, I. G., Takahashi, K., Yu, P., and Cone, R. D. (2004). Cholecystokininmediated suppression of feeding involves the brainstem melanocortin system. Nat. Neurosci. 7, 335-336. doi: 10.1038/nn1214

Faris, P. L., Hofbauer, R. D., Daughters, R., Vandenlangenberg, E., Iversen, L., Goodale, R. L., et al. (2008). Destabilization of the positive vagovagal reflex in bulimia nervosa
Physiol. Behav. 94, 136-153. doi: 10.1016/j.physbeh.2007.11.036

Fox, E. A. (2013). Vagal afferent controls of feeding: a possible role for gastrointestinal BDNF. Clin. Auton. Res. 23, 15-31. doi: 10.1007/s10286012-0170-x

Fox, E. A., Phillips, R. J., Baronowsky, E. A., Byerly, M. S., Jones, S., and Powley, T. L. (2001). Neurotrophin-4 deficient mice have a loss of vagal intraganglionic mechanoreceptors from the small intestine and a disruption of short-term satiety. J. Neurosci. 21, 8602-8615.

Fox, E. A., Phillips, R. J., Martinson, F. A., Baronowsky, E. A., and Powley, T. L. (2000). Vagal afferent innervation of smooth muscle in the stomach and duodenum of the mouse: morphology and topography. J. Comp. Neurol. 428, 558-576.

Fox, E. A., and Powley, T. L. (1986) Tracer diffusion has exaggerated CNS maps of direct preganglionic innervation of pancreas. J. Auton. Nerv. Syst. 15, 55-69. doi: 10.1016/ 0165-1838(86)90079-2

Fukuoka, T., Kobayashi, K., Yamanaka, H., Obata, K., Dai, Y., and Noguchi K. (2008). Comparative study of the distribution of the alpha-subunits of voltage-gated sodium channels in normal and axotomized rat dorsal root ganglion neurons. J. Comp. Neurol. 510, 188-206. doi: $10.1002 / \mathrm{cne} .21786$

Furness, J. B. (2006). The organisation of the autonomic nervous system: peripheral connections. Auton. Neurosci. 130, 1-5. doi: 10.1016/j.autneu.2006.05.003

Furness, J. B., Cho, H. J., Hunne, B., Hirayama, H., Callaghan, B. P., Lomax, A. E., et al. (2012). Identification of neurons that express ghrelin receptors in autonomic pathways originating from the spinal cord. Cell Tissue Res. 348, 397-405. doi: 10.1007/s00441-012-1405-9

Furness, J. B., and Costa, M. (1980) Types of nerves in the enteric nervous system. Neuroscience 5, 1-20. doi: 10.1016/0306-4522(80) 90067-6

Furness, J. B., Hunne, B., Matsuda, N., Yin, L., Russo, D., Kato, I., et al. (2011). Investigation of the presence of ghrelin in the central nervous system of the rat and mouse. Neuroscience 193, 1-9. doi: 10.1016/j.neuroscience.2011. 07.063

Gao, H., Glatzer, N. R., Williams, K. W., Derbenev, A. V., Liu, D., and Smith, B. N. (2009). 
Morphological and electrophysiological features of motor neurons and putative interneurons in the dorsal vagal complex of rats and mice. Brain Res. 1291, 40-52. doi: 10.1016/j.brainres.2009.07.024

Gautron, L., Lee, C., Funahashi, H., Friedman, J., Lee, S., and Elmquist, J. (2010a). Melanocortin-4 receptor expression in a vago-vagal circuitry involved in postprandial functions. J. Comp. Neurol. 518, 6-24.

Gautron, L., Lazarus, M., Scott, M. M., Saper, C. B., and Elmquist, J. K. (2010b). Identifying the efferent projections of leptin-responsive neurons in the dorsomedial hypothalamus using a novel conditional tracing approach. J. Comp. Neurol. 518, 2090-2108.

Gautron, L., Lee, C. E., Lee, S., and Elmquist, J. K. (2012). Melanocortin-4 receptor expression in different classes of spinal and vagal primary afferent neurons in the mouse. J. Comp. Neurol. 5201, 3933-3948.

Gautron, L., Rutkowski, J. M., Burton, M. D., Wei, W., Wan, Y., and Elmquist, J. K. (2013a). Neuronal and nonneuronal cholinergic structures in the mouse gastrointestinal tract and spleen. J. Comp. Neurol. doi: 10.1002/cne.23376. [Epub ahead of print].

Gautron, L., Zechner, J. F., and Aguirre, V. (2013b). Vagal innervation patterns following Roux-en-Y gastric bypass in the mouse. Int. J. Obes. (Lond). doi: 10.1038/ijo.2013.48. (in press).

Gautron, L., Sakata, I., Udit, S., Zigman, J. M., Wood, J. N., and Elmquist, J. K. (2011). Genetic tracing of Navl.8-expressing vagal afferents in the mouse. J. Comp. Neurol. 519, 3085-3101. doi: $10.1002 /$ cne.22667

Gelman, D. M., Noain, D., Avale, M. E., Otero, V., Low, M. J., and Rubinstein, M. (2003). Transgenic mice engineered to target Cre/loxPmediated DNA recombination into catecholaminergic neurons. Genesis 36, 196-202. doi: 10.1002/gene.10217

Gershon, M. D. (1981). The enteric nervous system. Annu. Rev. Neurosci. 4, 227-272. doi: 10.1146/annurev. ne.04.030181.001303

Gibbins, I. L., Jobling, P., and Morris, J. L. (2003). Functional organization of peripheral vasomotor pathways. Acta Physiol. Scand. 177, 237-245. doi: 10.1046/j.1365-201X.2003.01079.x

Gibbs, R. B. (1996). Fluctuations in relative levels of choline acetyltransferase mRNA in different regions of the rat basal forebrain across the estrous cycle: effects of estrogen and progesterone. J. Neurosci. 16, 1049-1055.

Gong, S., Zheng, C., Doughty, M. L., Losos, K., Didkovsky, N., Schambra, U. B., et al. (2003). A gene expression atlas of the central nervous system based on bacterial artificial chromosomes. Nature 425, 917-925. doi: 10.1038/nature02033

Gram, D. X., Ahren, B., Nagy, I., Olsen, U. B., Brand, C. L., Sundler, F., et al. (2007). Capsaicin-sensitive sensory fibers in the islets of Langerhans contribute to defective insulin secretion in Zucker diabetic rat, an animal model for some aspects of human type 2 diabetes. Eur. J. Neurosci. 25, 213-223. doi: 10.1111/j.1460-9568.2006.05261.x

Green, T., and Dockray, G. J. (1987). Calcitonin gene-related peptide and substance $\mathrm{P}$ in afferents to the upper gastrointestinal tract in the rat. Neurosci. Lett. 76, 151-156. doi: 10.1016/0304-3940(87)90707-5

Grybko, M. J., Hahm, E. T., Perrine, W., Parnes, J. A., Chick, W. S. Sharma, G., et al. (2011). A transgenic mouse model reveals fast nicotinic transmission in hippocampal pyramidal neurons. Eur. J. Neurosci. 33, 1786-1798. doi: 10.1111/j.14609568.2011.07671.x

Guijarro, A., Suzuki, S., Chen, C., Kirchner, H., Middleton, F. A., Nadtochiy, S., et al. (2007). Characterization of weight loss and weight regain mechanisms after Roux-en-Y gastric bypass in rats. Am. J. Physiol. Regul. Integr. Comp. Physiol. 293, R1474-R1489.

Gulbransen, B. D., and Sharkey, K. A. (2012). Novel functional roles for enteric glia in the gastrointestinal tract. Nat. Rev Gastroenterol. Hepatol. 9, 625-632. doi: 10.1038/nrgastro.2012.138

Hanna, L. A., Foreman, R. K., Tarasenko, I. A., Kessler, D. S., and Labosky, P. A. (2002). Requirement for Foxd3 in maintaining pluripotent cells of the early mouse embryo. Genes Dev. 16, 2650-2661. doi: 10.1101/gad.1020502

Harris, J. A., Wook Oh, S., and Zeng, H. (2012). Adeno-associated viral vectors for anterograde axonal tracing with fluorescent proteins in nontransgenic and cre driver mice. Curr. Protoc. Neurosci. 20, 1-18. doi: 10.1002/0471142301.ns0120s59

Heffner, C. S., Herbert Pratt, C., Babiuk, R. P., Sharma, Y. Rockwood, S. F., Donahue, L. R., et al. (2012). Supporting conditional mouse mutagenesis with a comprehensive cre characterization resource. Nat. Commun. 3, 1218 doi: $10.1038 /$ ncomms 2186

Howard, D. B., Powers, K., Wang, Y., and Harvey, B. K. (2008). Tropism and toxicity of adeno-associated viral vector serotypes 112567 8 , and 9 in rat neurons and glia in vitro. Virology 372, 24-34. doi 10.1016/j.virol.2007.10.007

Huo, L., Grill, H. J., and Bjorbaek, C. (2006). Divergent regulation of proopiomelanocortin neurons by leptin in the nucleus of the solitary tract and in the arcuate hypothalamic nucleus. Diabetes 55, 567-573. doi: $\quad 10.2337 /$ diabetes.55.03.06 $\mathrm{db} 05-1143$

Janig, W. (1996). Neurobiology of visceral afferent neurons: neuroanatomy, functions, organ regulations and sensations. Biol. Psychol. 42, 29-51. doi 10.1016/0301-0511(95)05145-7

Kay, M. A., Manno, C. S., Ragni, M. V., Larson, P. J., Couto, L. B., McClelland, A., et al. (2000). Evidence for gene transfer and expression of factor IX in haemophilia B patients treated with an AAV vector. Nat. Genet. 24 257-261. doi: 10.1038/73464

Kishi, T., Aschkenasi, C. J., Lee, C. E., Mountjoy, K. G., Saper, C. B., and Elmquist, J. K. (2003). Expression of melanocortin 4 receptor mRNA in the central nervous system of the rat. J. Comp. Neurol. 457, 213-235. doi: 10.1002/cne.10454

Klein, R. L., Hamby, M. E., Gong, Y., Hirko, A. C., Wang, S., Hughes, J. A., et al. (2002). Dose and promoter effects of adeno-associated viral vector for green fluorescent protein expression in the rat brain Exp. Neurol. 176, 66-74. doi: 10.1006/exnr.2002.7942

Kollarik, M., Carr, M. J., Ru, F., Ring, C. J., Hart, V. J., Murdock, P., et al. (2010). Transgene expression and effective gene silencing in vagal afferent neurons in vivo using recombinant adeno-associated virus vectors. J. Physiol. (Lond.) 588, 4303-4315 doi: 10.1113/jphysiol.2010.192971

Kral, J. G. (1978). Vagotomy for treatment of severe obesity. Lance 1, 307-308 doi: 10.1016/S01406736(78)90074-0

Krashes, M. J., Koda, S., Ye, C., Rogan, S. C., Adams, A. C., Cusher, D. S., et al. (2011). Rapid, reversible activation of AgRP neurons drives feeding behavior in mice. J. Clin. Invest. 121, 1424-1428. doi: 10.1172/JCI46229

Krenzer, M., Anaclet, C., Vetrivelan, R., Wang, N., Vong, L., Lowell, B. B., et al. (2011). Brainstem and spinal cord circuitry regulating REM sleep and muscle atonia. PLoS ONE 6:e24998. doi: 10.1371/journal.pone.0024998

Laird, J. M., Souslova, V., Wood, J. N., and Cervero, F. (2002). Deficits in visceral pain and referred hyperalgesia in Nav1.8 (SNS/PN3)-null mice. J. Neurosci. 22, 8352-8356.

Larauche, M., Mulak, A., and Tache, Y. (2012). Stress and visceral pain: from animal models to clinical therapies. Exp. Neurol. 233, 49-67. doi: 10.1016/j.expneurol.2011.04.020

Lazarus, M., Yoshida, K., Coppari, R., Bass, C. E., Mochizuki, T. Lowell, B. B., et al. (2007). EP3 prostaglandin receptors in the median preoptic nucleus are critical for fever responses. Nat. Neurosci. 10, 1131-1133. doi: 10.1038/nn1949

Li, L., Rutlin, M., Abraira, V. E., Cassidy, C., Kus, L., Gong, S., et al. (2011). The functional organization of cutaneous lowthreshold mechanosensory neurons. Cell 147, 1615-1627. doi: 10.1016/j.cell.2011.11.027

Lindeberg, J., Usoskin, D., Bengtsson, H., Gustafsson, A., Kylberg, A., Soderstrom, S., et al. (2004). Transgenic expression of Cre recombinase from the tyrosine hydroxylase locus. Genesis 40, 67-73. doi: 10.1002/gene.20065

Lindsay, T. H., Halvorson, K. G., Peters, C. M., Ghilardi, J. R., Kuskowski, M. A., Wong, G. Y., et al. (2006). A quantitative analysis of the sensory and sympathetic innervation of the mouse pancreas. Neuroscience 137, 1417-1426. doi 10.1016/j.neuroscience.2005.10.055

Liu, B., Hammer, G. D., Rubinstein M., Mortrud, M., and Low, M J. (1992). Identification of DNA elements cooperatively activating proopiomelanocortin gene expression in the pituitary glands of transgenic mice. Mol. Cell. Biol. 12, 3978-3990.

Liu, H., Kishi, T., Roseberry, A. G., Cai, X., Lee, C. E., Montez, J. M., et al. (2003). Transgenic mice expressing green fluorescent protein under the control of the melanocortin-4 receptor promoter. J. Neurosci. 23, 7143-7154.

Livet, J., Weissman, T. A., Kang, H., Draft, R. W., Lu, J., Bennis, R. A., et al. (2007). Transgenic strategies for combinatorial expression of fluorescent proteins in the nervous system. Nature 450, 56-62. doi: 10.1038/nature 06293

Loewy, A. D., and Spyer, K. M. (1990). "Vagal preganglionic neurons," in Central Regulation of Autonomic Functions, eds A. D. Loewy, K. M. 
Spyer (New York, NY: Oxford university Press), 533-538.

Lomax, A. E., Linden, D. R., Mawe, G. M., and Sharkey, K. A. (2006). Effects of gastrointestinal inflammation on enteroendocrine cells and enteric neural reflex circuits. Auton. Neurosci. 126-127, 250-257. doi: 10.1016/j.autneu. 2006.02.015

Lowenstein, P. R., and Castro, M. G. (2002). Progress and challenges in viral vector-mediated gene transfer to the brain. Curr. Opin. Mol. Ther. 4, 359-371.

Luo, L., Callaway, E. M., and Svoboda, K. (2008). Genetic dissection of neural circuits. Neuron 57, 634-660. doi: 10.1016/j.neuron.2008.01.002

Luquet, S., Perez, F. A., Hnasko, T. S., and Palmiter, R. D. (2005). NPY/AgRP neurons are essential for feeding in adult mice but can be ablated in neonates. Science 310, 683-685. doi: 10.1126/science. 1115524

Madisen, L., Zwingman, T. A., Sunkin, S. M., Oh, S. W., Zariwala, H. A., $\mathrm{Gu}, \mathrm{H}$., et al. (2010). A robust and high-throughput Cre reporting and characterization system for the whole mouse brain. Nat. Neurosci. 13, 133-140. doi: 10.1038/nn.2467

Mastitskaya, S., Marina, N., Gourine, A., Gilbey, M. P., Spyer, K. M., Teschemacher, A. G., et al. (2012). Cardioprotection evoked by remote ischaemic preconditioning is critically dependent on the activity of vagal pre-ganglionic neurones. Cardiovasc. Res. 95, 487-494. doi: $10.1093 / \mathrm{cvr} / \mathrm{cvs} 212$

Mawe, G. M., Talmage, E. K., Cornbrooks, E. B., Gokin, A. P., Zhang, L., and Jennings, L. J. (1997). Innervation of the gallbladder: structure, neurochemical coding, and physiological properties of guinea pig gallbladder ganglia. Microsc. Res. Tech. 39, 1-13.

Mayer, E. A., and Collins, S. M. (2002). Evolving pathophysiologic models of functional gastrointestinal disorders. Gastroenterology 122, 2032-2048. doi: 10.1053/gast.2002. 33584

McCoy, E. S., Taylor-Blake, B., and Zylka, M. J. (2012). CGRPalphaexpressing sensory neurons respond to stimuli that evoke sensations of pain and itch. PLOS ONE 7:e36355. doi: 10.1371/journal.pone.0036355

McDougal, D. H., Hermann, G. E., and Rogers, R. C. (2011). Vagal afferent stimulation activates astrocytes in the nucleus of the solitary tract via AMPA receptors: evidence of an atypical neuralglial interaction in the brainstem.
J. Neurosci. 31, 14037-14045. doi: 10.1523/JNEUROSCI.2855-11.2011

McLenachan, S., Goldshmit, Y., Fowler, K. J., Voullaire, L., Holloway, T. P., Turnley, A. M., et al. (2008). Transgenic mice expressing the Peripherin-EGFP genomic reporter display intrinsic peripheral nervous system fluorescence. Transgenic Res. 17, 1103-1116. doi: 10.1007/s11248-008-9210-7

Meissner, G. (1857). Über die Nerven der Darmwand. Z. Ration. Med. 8, 364-366.

Mercer, E. H., Hoyle, G. W., Kapur, R. P., Brinster, R. L., and Palmiter, R. D. (1991). The dopamine betahydroxylase gene promoter directs expression of E. coli lacZ to sympathetic and other neurons in adult transgenic mice. Neuron 7, 703-716. doi: 10.1016/0896-6273(91)90274-4

Meyrelles, S. S., Sharma, R. V., Whiteis, C. A., Davidson, B. L., and Chapleau, M. W. (1997). Adenovirus-mediated gene transfer to cultured nodose sensory neurons. Brain Res. Mol. Brain Res. 51, 33-41. doi: 10.1016/S0169-328X (97)00212-X

Mishra, S. K., Tisel, S. M., Orestes, P., Bhangoo, S. K., and Hoon, M. A. (2011). TRPV1-lineage neurons are required for thermal sensation. $Е M B O$ J. 30, 582-593. doi: 10.1038/emboj. 2010.325

Mitsui, R. (2009). Characterisation of calcitonin gene-related peptideimmunoreactive neurons in the myenteric plexus of rat colon. Cell Tissue Res. 337, 37-43. doi: 10.1007/s00441-009-0798-6

Morris, J. L., Gibbins, I. L., Furness, J. B., Costa, M., and Murphy, R. (1985). Co-localization of neuropeptide $\mathrm{Y}$, vasoactive intestinal polypeptide and dynorphin in nonnoradrenergic axons of the guinea pig uterine artery. Neurosci. Lett. 62 , 31-37. doi: 10.1016/0304-3940(85) 90280-0

Mulderry, P. K., Ghatei, M. A., Spokes, R. A., Jones, P. M., Pierson, A. M., Hamid, Q. A., et al. (1988). Differential expression of alpha-CGRP and beta-CGRP by primary sensory neurons and enteric autonomic neurons of the rat. Neuroscience 25, 195-205. doi: 10.1016/0306-4522 (88)90018-8

Mundell, N. A., Plank, J. L., LeGrone, A. W., Frist, A. Y., Zhu, L., Shin, M. K., et al. (2012). Enteric nervous system specific deletion of Foxd3 disrupts glial cell differentiation and activates compensatory enteric progenitors. Dev. Biol. 363, 373-387. doi: 10.1016/j.ydbio.2012.01.003
Murray, S. A., Eppig, J. T., Smedley, D., Simpson, E. M., and Rosenthal, N. (2012). Beyond knockouts: cre resources for conditional mutagenesis. Mamm. Genome 23, 587-599. doi: 10.1007/s00335-012-9430-2

Naciff, J. M., Behbehani, M. M., Misawa, H., and Dedman, J. R. (1999). Identification and transgenic analysis of a murine promoter that targets cholinergic neuron expression. J. Neurochem. 72, 17-28. doi: 10.1046/j.14714159.1999.0720017.x

Nguyen, Q. T., Sanes, J. R., and Lichtman, J. W. (2002). Pre-existing pathways promote precise projection patterns. Nat. Neurosci. 5, 861-867. doi: 10.1038/nn905

Nogueiras, R., Tschop, M. H., and Zigman, J. M. (2008). Central nervous system regulation of energy metabolism: ghrelin versus leptin. Ann. N.Y. Acad. Sci. 1126, 14-19. doi: 10.1196/annals.1433.054

Obermayr, F., Stamp, L. A., Anderson, C. R., and Young, H. M. (2013). Genetic fate-mapping of tyrosine hydroxylase-expressing cells in the enteric nervous system. Neurogastroenterol. Motil. 25, e283-e291. doi: 10.1111/nmo.12105

Obici, S., Feng, Z., Tan, J., Liu, L., Karkanias, G., and Rossetti, L. (2001). Central melanocortin receptors regulate insulin action. J. Clin. Invest. 108, 1079-1085.

Oliva, A. A. Jr., Jiang, M., Lam, T., Smith, K. L., and Swann, J. W. (2000). Novel hippocampal interneuronal subtypes identified using transgenic mice that express green fluorescent protein in GABAergic interneurons. J. Neurosci. 20, 3354-3368.

Padilla, S. L., Reef, D., and Zeltser, L. M. (2012). Defining POMC neurons using transgenic reagents: impact of transient Pomc expression in diverse immature neuronal populations. Endocrinology 153, 1219-1231. doi: 10.1210/en.2011-1665

Paré, A. (1968). Of the Distribution of the Nerves to the Natural Parts, Collected Works of Ambroise Pare Translated Out of the Latin by Thomas Johnson from First English edition 1634. New York, NY: Milford House Inc

Patterson, L. M., Zheng, H., and Berthoud, H. R. (2002). Vagal afferents innervating the gastrointestinal tract and CCKA-receptor immunoreactivity. Anat. Rec. 266, 10-20. doi: 10.1002/ar.10026

Peitl, B., Dobronte, R., Nemeth, J., Mezey, G., Kovacs, P., Paragh, G., et al. (2005). The prandial insulin sensitivity-modifying effect of vagal stimulation in rats. Metab. Clin. Exp. 54, 579-583. doi: 10.1016/j.metabol.2004.11.014

Phillips, R. J., Baronowsky, E. A., and Powley, T. L. (2000). Regenerating vagal afferents reinnervate gastrointestinal tract smooth muscle of the rat. J. Comp. Neurol. 421, 325-346.

Phillips, R. J., and Powley, T. L. (1998). Gastric volume detection after selective vagotomies in rats. Am. J. Physiol. 274, R1626-R1638.

Phillips, R. J., and Powley, T. L. (2005). Plasticity of vagal afferents at the site of an incision in the wall of the stomach. Auton. Neurosci. 123, 44-53. doi: 10.1016/j.autneu.2005. 08.009

Phillips, R. J., and Powley, T. L. (2007). Innervation of the gastrointestinal tract: patterns of aging. Auton. Neurosci. 136, 1-19. doi: 10.1016/j.autneu.2007.04.005

Pocai, A., Lam, T. K., GutierrezJuarez, R., Obici, S., Schwartz, G. J., Bryan, J., et al. (2005). Hypothalamic K(ATP) channels control hepatic glucose production. Nature 434, 1026-1031. doi: 10.1038 /nature 03439

Powley, T. L. (2000). Vagal input to the enteric nervous system. Gut 47(Suppl. 4), iv30-iv32. discussion: iv36.

Powley, T. L., Chi, M. M., Schier, L. A., and Phillips, R. J. (2005) Obesity: should treatments target visceral afferents? Physiol. Behav. 86, 698-708.

Powley, T. L., and Phillips, R. J. (2011). Vagal intramuscular array afferents form complexes with interstitial cells of Cajal in gastrointestinal smooth muscle: analogues of muscle spindle organs? Neuroscience $186,188-200$.

Powley, T. L., Spaulding, R. A., and Haglof, S. A. (2011). Vagal afferent innervation of the proximal gastrointestinal tract mucosa: chemoreceptor and mechanoreceptor architecture. J. Comp. Neurol. 519, 644-660. doi: $10.1002 / \mathrm{cne}$ 22541

Raybould, H. E. (2012). Gut microbiota, epithelial function and derangements in obesity. J. Physiol. (Lond.) 590, 441-446.

Razavi, R., Chan, Y., Afifiyan, F. N., Liu, X. J., Wan, X., Yantha, J., et al. (2006). TRPV1+ sensory neurons control beta cell stress and islet inflammation in autoimmune diabetes. Cell 127, 1123-1135. doi: 10.1016/j.cell.2006.10.038

Rinaman, L., Roesch, M. R., and Card, J. P. (1999). Retrograde transynaptic pseudorabies virus infection of central autonomic circuits in neonatal 
rats. Brain Res. Dev. Brain Res. 114, 207-216. doi: 10.1016/S0165-3806 (99)00039-5

Rinaman, L., and Schwartz, G. (2004). Anterograde transneuronal viral tracing of central viscerosensory pathways in rats. J. Neurosci. 24, 2782-2786. doi: 10.1523/JNEUROSCI.5329-03.2004

Ritter, S., and Dinh, T. T. (1992). Age-related changes in capsaicininduced degeneration in rat brain. J. Comp. Neurol. 318, 103-116. doi: 10.1002/cne.903180108

Rohner-Jeanrenaud, F., Ionescu, E., and Jeanrenaud, B. (1983). The origins and role of efferent vagal nuclei in hyperinsulinemia in hypothalamic and genetically obese rodents. J. Auton. Nerv. Syst. 9, 173-184. doi: 10.1016/0165-1838 (83)90139-X

Rossi, J., Balthasar, N., Olson, D., Scott, M., Berglund, E., Lee, C. E., et al. (2011). Melanocortin-4 receptors expressed by cholinergic neurons regulate energy balance and glucose homeostasis. Cell Metab. 13, 195-204. doi: 10.1016/j.cmet.2011.01.010

Rossi, J., Herzig, K. H., Voikar, V., Hiltunen, P. H., Segerstrale, M., and Airaksinen, M. S. (2003). Alimentary tract innervation deficits and dysfunction in mice lacking GDNF family receptor alpha2. J. Clin. Invest. 112, 707-716.

Rozman, J., and Bunc, M. (2004). Modulation of visceral function by selective stimulation of the left vagus nerve in dogs. Exp. Physiol. 89, 717-725. doi: 10.1113/expphysiol.2004.027953

Savitt, J. M., Jang, S. S., Mu, W., Dawson, V. L., and Dawson, T. M. (2005). Bcl-x is required for proper development of the mouse substantia nigra. J. Neurosci. 25, 6721-6728. doi: 10.1523/JNEUROSCI.0760-05.2005

Sawada, Y., Kajiwara, G., Iizuka, A., Takayama, K., Shuvaev, A. N., Koyama, C., et al. (2010). High transgene expression by lentiviral vectors causes maldevelopment of Purkinje cells in vivo. Cerebellum 9, 291-302. doi: 10.1007/s12311-0100161-1

Schnepp, B. C., Clark, K. R., Klemanski, D. L., Pacak, C. A., and Johnson, P. R. (2003). Genetic fate of recombinant adeno-associated virus vector genomes in muscle. J. Virol. 77, 3495-3504. doi: 10.1128/JVI.77. 6.3495-3504.2003

Schonig, K., Freundlieb, S., and Gossen, M. (2013). Tet-Transgenic Rodents: a comprehensive, up-to date database.
Transgenic Res. 22, 251-254. doi: 10.1007/s11248-012-9660-9

Schonig, K., Weber, T., Frommig, A., Wendler, L., Pesold, B., Djandji, D., et al. (2012). Conditional gene expression systems in the transgenic rat brain. BMC Biol. 10:77. doi: 10.1186/1741-7007-10-77

Schuster, D. J., Dykstra, J. A., Riedl, M. S., Kitto, K. F., Honda, C. N., McIvor, R. S., et al. (2013). Visualization of spinal afferent innervation in the mouse colon by AAV8-mediated GFP expression. Neurogastroenterol. Motil. 25, e89-e100. doi: 10.1111/nmo.12057

Schwartz, G. J., Salorio, C. F., Skoglund, C., and Moran, T. H. (1999). Gut vagal afferent lesions increase meal size but do not block gastric preload-induced feeding suppression. Am. J. Physiol. 276, R1623-R1629.

Scott, M. M., Williams, K. W., Rossi, J., Lee, C. E., and Elmquist, J. K (2011). Leptin receptor expression in hindbrain Glp-1 neurons regulates food intake and energy balance in mice. J. Clin. Invest. 121, 2413-2421. doi: 10.1172/JCI43703

Shaner, N. C., Campbell, R. E., Steinbach, P. A., Giepmans, B. N., Palmer, A. E., and Tsien, R. Y. (2004). Improved monomeric red, orange and yellow fluorescent proteins derived from Discosoma sp.red fluorescent protein. Nat. Biotechnol. 22, 1567-1572. doi: 10.1038/nbt1037

Sharkey, K. A., and Mawe, G. M. (2012). Neurogastroenterology in 2011, Emerging concepts in neurogastroenterology and motility. Nat. Rev. Gastroenterol. Hepatol. 9, 74-76. doi: 10.1038/nrgastro.2011.247

Sharkey, K. A., Williams, R. G., and Dockray, G. J. (1984). Sensory substance $\mathrm{P}$ innervation of the stomach and pancreas. Demonstration of capsaicin-sensitive sensory neurons in the rat by combined immunohistochemistry and retrograde tracing. Gastroenterology 87, 914-921.

Shields, S. D., Ahn, H. S., Yang, Y., Han, C., Seal, R. P., Wood, J. N., et al. (2012). Nav1.8 expression is not restricted to nociceptors in mouse peripheral nervous system. Pain 153, 2017-2030.

Shimazu, T. (1971). Regulation of glycogen metabolism in liver by the autonomic nervous system. V. Activation of glycogen synthetase by vagal stimulation. Biochim. Biophys. Acta 252, 28-38. doi: 10.1016/03044165(71)90089-4

Shimazu, T., and Fujimoto, T. (1971) Regulation of glycogen metabolism in liver by the autonomic nervous system. IV. Neural control of glycogen biosynthesis. Biochim. Biophys. Acta 252, 18-27. doi: 10.1016/03044165(71)90088-2

Shin, A. C., Zheng, H., and Berthoud, H. R. (2012). Vagal innervation of the hepatic portal vein and liver is not necessary for Roux-en-Y gastric bypass surgeryinduced hypophagia, weight loss, and hypermetabolism. Ann. Surg. 255, 294-301. doi 10.1097/SLA.0b013e31823e71b7

Stearns, A. T., Balakrishnan, A. Radmanesh, A., Ashley, S. W. Rhoads, D. B., and Tavakkolizadeh, A. (2012). Relative contributions of afferent vagal fibers to resistance to diet-induced obesity. Dig. Dis. Sci. 57, 1281-1290. doi 10.1007/s10620-011-1968-4

Sterner, M. R., Fox, E. A., and Powley, T. L. (1985). A retrograde tracer strategy using True Blue to label the preganglionic parasympathetic innervation of the abdominal viscera J. Neurosci. Methods 14, 273-280. doi: 10.1016/0165-0270(85)90090-1

Stine, Z. E., Huynh, J. L., Loftus S. K., Gorkin, D. U., Salmasi, A. H., Novak, T., et al. (2009). Oligodendroglial and panneural crest expression of Cre recombinase directed by Sox 10 enhancer. Genesis 47, 765-770. doi: 10.1002/dvg.20559

Stirling, L. C., Forlani, G., Baker, M. D., Wood, J. N., Matthews, E. A., Dickenson, A. H., et al. (2005) Nociceptor-specific gene deletion using heterozygous NaV1.8-Cre recombinase mice. Pain 113, 27-36. doi: 10.1016/j.pain.2004.08.015

Storek, B., Reinhardt, M., Wang, C., Janssen, W. G., Harder, N. M., Banck, M. S., et al. (2008). Sensory neuron targeting by self-complementary AAV8 via lumbar puncture for chronic pain. Proc. Natl. Acad. Sci. U.S.A. 105, 1055-1060. doi: 10.1073/pnas.0708003105

Tallini, Y. N., Shui, B., Greene, K. S. Deng, K. Y., Doran, R., Fisher, P. J., et al. (2006). BAC transgenic mice express enhanced green fluorescent protein in central and peripheral cholinergic neurons. Physiol. Genomics 27, 391-397. doi: 10.1152/physiolgenomics.00092.2006

Tenenbaum, L., Chtarto, A., Lehtonen, E., Velu, T., Brotchi, J., and Levivier, M. (2004). Recombinant AAVmediated gene delivery to the central nervous system. J. Gene Med. 6(Suppl. 1), S212-S222. doi 10.1002/jgm.506
Tiveron, M. C., Hirsch, M. R., and Brunet, J. F. (1996). The expression pattern of the transcription factor Phox2 delineates synaptic pathways of the autonomic nervous system. J. Neurosci. 16, 7649-7660.

Travagli, R. A., Hermann, G. E., Browning, K. N., and Rogers, R. C. (2003). Musings on the wanderer: what's new in our understanding of vago-vagal reflexes? III. Activity-dependent plasticity in vago-vagal reflexes controlling the stomach. Am. J. Physiol. Gastrointest. Liver Physiol. 284, G180-G187.

Troy, C. M., Brown, K., Greene, L. A., and Shelanski, M. L. (1990). Ontogeny of the neuronal intermediate filament protein, peripherin, in the mouse embryo. Neuroscience 36, 217-237. doi: 10.1016/03064522(90)90364-A

Troy, S., Soty, M., Ribeiro, L., Laval, L. Migrenne, S., Fioramonti, X., et al. (2008). Intestinal gluconeogenesis is a key factor for early metabolic changes after gastric bypass but not after gastric lap-band in mice. Cell Metab. 8, 201-211. doi: 10.1016/j.cmet.2008.08.008

Tucker, K. L., Meyer, M., and Barde, Y. A. (2001). Neurotrophins are required for nerve growth during development. Nat. Neurosci. 4, 29-37. doi: 10.1038/82868

Uno, K., Katagiri, H., Yamada, T., Ishigaki, Y., Ogihara, T., Imai, J., et al. (2006). Neuronal pathway from the liver modulates energy expenditure and systemic insulin sensitivity. Science 312, 1656-1659. doi: 10.1126/science. 1126010

Val-Laillet, D., Biraben, A. Randuineau, G., and Malbert, C. H. (2010). Chronic vagus nerve stimulation decreased weight gain, food consumption and sweet craving in adult obese minipigs. Appetite 55, 245-252. doi: 10.1016/j.appet.2010.06.008

Vulchanova, L., Schuster, D. J., Belur, L. R., Riedl, M. S., Podetz-Pedersen, K. M., Kitto, K. F., et al. (2010). Differential adeno-associated virus mediated gene transfer to sensory neurons following intrathecal delivery by direct lumbar puncture. $\mathrm{Mol}$. Pain 6, 31.

Walter, G. C., Phillips, R. J., Baronowsky, E. A., and Powley, T. L. (2009). Versatile, highresolution anterograde labeling of vagal efferent projections with dextran amines. J. Neurosci. Methods 178, 1-9. doi: 10.1016/j.jneumeth.2008.11.003

Wang, F. B., and Powley, T. L. (2000). Topographic inventories of vagal 
afferents in gastrointestinal muscle. J. Comp. Neurol. 421, 302-324.

Wang, Z. J., and Neuhuber, W. L. (2003). Intraganglionic laminar endings in the rat esophagus contain purinergic $\mathrm{P} 2 \mathrm{X} 2$ and P2X3 receptor immunoreactivity. Anat. Embryol. 207, 363-371. doi: 10.1007/s00429-003-0351-4

Weissman, T. A., Sanes, J. R., Lichtman, J. W., and Livet, J. (2011). Generation and imaging of Brainbow mice. Cold Spring Harb. Protoc. 2011, 851-856.

Westerman, R. A., Delaney, C., IvamyPhillips, A., Horowitz, M., and Roberts, A. (1989). Concordance between different measures of small sensory and autonomic fibre neuropathy in diabetes mellitus. Clin. Exp. Neurol. 26, 51-63.

Whitney, M. A., Crisp, J. L., Nguyen, L. T., Friedman, B., Gross, L. A., Steinbach, P., et al. (2011). Fluorescent peptides highlight peripheral nerves during surgery in mice. Nat. Biotechnol. 29, 352-356. doi: 10.1038/nbt.1764

Witten, I. B., Steinberg, E. E., Lee, S. Y., Davidson, T. J., Zalocusky, K. A., Brodsky, M., et al. (2011). Recombinase-driver rat lines: tools, techniques, and optogenetic application to dopamine-mediated reinforcement. Neuron 72, 721-733. doi: 10.1016/j.neuron.2011.10.028

Yi, C. X., and Tschop, M. H. (2012). Brain-gut-adipose-tissue communication pathways at a glance. Dis. Model. Mech. 5, 583-587. doi: 10.1242/dmm.009902

Young, H. M., Bergner, A. J., Anderson, R. B., Enomoto, H., Milbrandt, J., Newgreen, D. F., et al. (2004). Dynamics of neural crest-derived cell migration in the embryonic mouse gut. Dev. Biol. 270, 455-473. doi: 10.1016/j.ydbio.2004. 03.015

Zagorodnyuk, V. P., Brookes, S. J., and Spencer, N. J. (2010). Structurefunction relationship of sensory endings in the gut and bladder. Auton. Neurosci. 153, 3-11. doi: 10.1016/j.autneu.2009.07.018

Zechner, J. F., Mirshahi, U. L., Satapati, S., Berglund, E. D., Rossi, J., Scott, M. M., et al. (2012). WeightIndependent effects of roux-en-y gastric bypass on glucose homeostasis via melanocortin- 4 receptors in mice and humans. Gastroenterology 144, 580-590.

Zheng, H., Patterson, L. M., Rhodes, C. J., Louis, G. W., Skibicka, K. P., Grill,
H. J., et al. (2010). A potential role for hypothalamomedullary POMC projections in leptin-induced suppression of food intake. Am. J. Physiol. Regul. Integr. Comp. Physiol. 298, R720-R728.

Zhou, L., Nepote, V., Rowley, D. L., Levacher, B., Zvara, A., Santha, M., et al. (2002). Murine peripherin gene sequences direct Cre recombinase expression to peripheral neurons in transgenic mice. FEBS Lett. 523, 68-72. doi: $\quad 10.1016 / S 0014-5793(02)$ 02936-8

Zigman, J. M., Jones, J. E., Lee, C. E., Saper, C. B., and Elmquist, J. K. (2006). Expression of ghrelin receptor mRNA in the rat and the mouse brain. J. Comp. Neurol. 494, 528-548. doi: 10.1002/cne. 20823

Zimmermann, K., Leffler, A., Babes, A., Cendan, C. M., Carr, R. W., Kobayashi, J., et al. (2007). Sensory neuron sodium channel Nav1.8 is essential for pain at low temperatures. Nature 447, 855-858. doi 10.1038/nature05880

Zurborg, S., Piszczek, A., Martinez, C., Hublitz, P., Al Banchaabouchi, M., Moreira, P., et al. (2011). Generation and characterization of an Advillin-Cre driver mouse line. Mol. Pain 7, 66

Conflict of Interest Statement: The authors declare that the research was conducted in the absence of any commercial or financial relationships that could be construed as a potential conflict of interest.

Received: 11 April 2013; accepted: 12 July 2013; published online: 31 July 2013.

Citation: Udit S and Gautron L (2013)

Molecular anatomy of the gut-brain axis revealed with transgenic technologies: implications in metabolic research. Front. Neurosci. 7:134. doi: 10.3389/ fnins.2013.00134

This article was submitted to Frontiers in Neuroendocrine Science, a specialty of Frontiers in Neuroscience.

Copyright (c) 2013 Udit and Gautron. This is an open-access article distributed under the terms of the Creative Commons Attribution License (CC BY). The use, distribution or reproduction in other forums is permitted, provided the original author(s) or licensor are credited and that the original publication in this journal is cited, in accordance with accepted academic practice. No use, distribution or reproduction is permitted which does not comply with these terms. 